\title{
Influence of tropho-climatic environment and reproduction on lipid composition of the euphausiid Meganyctiphanes norvegica in the Ligurian Sea, the Clyde Sea and the Kattegat
}

\author{
Eric Albessard, Patrick Mayzaud* \\ Observatoire Océanologique, Océanographie Biochimique et Ecologie, Laboratoire Océanographique de Villefranche, \\ LOV-UMR 7093, BP 28, 06230 Villefranche sur Mer, France
}

\begin{abstract}
Lipid content and lipid-class distribution in the northern krill Meganyctiphanes norvegica (M. Sars, 1857) was investigated in 3 contrasting (in terms of climatic and trophic conditions) areas: the Ligurian Sea, the Clyde Sea and the Kattegat. Seasonal differences in the lipid content of krill were closely related to food supply coupled with the krill reproductive state in both the Ligurian Sea and in the Clyde Sea. In the Kattegat, the lipid reserves of reproductive krill were low and probably used continuously over a longer reproduction period and successive spawning cycles. In the Ligurian and Clyde Seas, female krill lost 55 and $33 \%$ of their cephalothorax (CT) lipids through spawning. The content of triacylglycerol (TAG) and phosphatidylcholine (PC), both major lipids in the CT, were higher when food conditions were optimal at the 3 sites, and were correlated to chlorophyll a ( $\mathrm{chl} \mathrm{a)} \mathrm{concentration} \mathrm{in} \mathrm{the} \mathrm{Ligurian} \mathrm{and} \mathrm{Clyde} \mathrm{Seas.} \mathrm{The} \mathrm{influence} \mathrm{of} \mathrm{reproduction}$ on lipid-class distribution in the Clyde and Ligurian Seas was expressed by a large decrease in PC and TAG throughout spawning, while in the Kattegat PC and TAG levels were low irrespective of the reproductive state. The relative influence of environmental and physiological factors on the lipid distribution of krill in the $\mathrm{CT}$ and abdomen (AB) among the 3 locations was evaluated using principal components analysis. In the CT, TAG and PC along with minor lipids were major discriminating factors and were strongly correlated to total lipid content and chl a concentrations. For reproducive krill, marked differences in the $\mathrm{CT}$ and $\mathrm{AB}$ indicated covariation between reproduction and trophic conditions. The influence of the physical environment on $M$. norvegica at sexual rest found expression in variation in the membrane lipids in the $A B$ across the different temperature and salinity regimes at the 3 sites. The results are discussed in terms of adaptive mechanisms involving lipid distribution and metabolism developed by the species.
\end{abstract}

KEY WORDS: Krill · Lipids · Adaptation · Reproduction · Trophic environment · Triacylglycerol · Phospholipids $\cdot$ Meganyctiphanes norvegica $\cdot$ Temperature $\cdot$ Salinity

\section{INTRODUCTION}

The euphausiid Meganyctiphanes norvegica is an important component of the macroplanktonic community in the Atlantic Ocean and is a main food source for species of higher trophic levels such as fishes, birds and whales (Einarsson 1945, Pearcy et al. 1979). The wide distribution area of this krill species, from the Arctic to the Mediterranean and from Western Europe to the east coast of Canada (Mauchline \& Fisher 1969), covers contrasting biotopes. Thus, M. norvegica survives and achieves its biological cycle within a wide range of temperatures ( 1 to $15^{\circ} \mathrm{C}$ ) and salinity (27 to 39 psu) (Lindley 1982, Astthorsson \& Gislason 1997), reflecting the extreme plasticity of its physiology.

The present study was part of a European program (PEP, MAST III) on the physiological ecology of Meganyctiphanes norvegica in 3 areas differing both in terms of climatic and trophic conditions. The Clyde Sea (Scotland) is $\operatorname{cool}\left(7\right.$ to $\left.11^{\circ} \mathrm{C}\right)$ throughout the year, 
with a phytoplankton bloom in late spring to early summer (Matthews et al. 1999). At a similar latitude to the Clyde Sea, the Kattegat (Denmark) is a shallowwater body with marked temperature $\left(3\right.$ to $\left.19^{\circ} \mathrm{C}\right)$ and salinity (27 to $39 \mathrm{psu}$ ) stratification in summer, influenced by the outflow of Baltic waters (Matthews et al. 1999). The Kattegat is characterised by high densities of zooplankters (mostly copepods), while the Ligurian Sea is warm $\left(13\right.$ to $22^{\circ} \mathrm{C}$ ), oligotrophic and stable (De la Bigne 1985). In recent studies, $M$. norvegica showed an opportunistic feeding behaviour, feeding either on phytoplankton or zooplankton, when these were present in sufficient concentrations (Båmstedt \& Karlson 1998, Onsrud \& Kaartvedt 1998, Lass et al. 2001).

The lipid content and distribution of Meganyctiphanes norvegica have already been documented as dietary indicators (Saether et al. 1986, Mayzaud et al. 1999, Virtue et al. 2000), reproduction (Båmstedt 1976, Cuzin-Roudy 1993, Cuzin-Roudy et al. 1999) and survival during periods of low food availability (Buchholz \& Prado-Fiedler 1987, Mayzaud et al. 1999). Because of their essential functions as an energy source, as structural components of cell membranes and as effectors for cell signalling and ATP production (Ohtsuka et al. 1993), lipids are likely to display not only metabolic but also structural adaptations in response to different environmental conditions. The study of the combined influence of temperature and trophic changes on lipids is difficult, because specific lipids can be affected differently, depending on their principal localisation in an organism. Thus, the function of lipids in the main body compartments or storage organs should be considered when examining climatic and trophic effects. The cephalothorax (CT) complex is the major site of lipid synthesis and storage (digestive gland, fat body, ovary), while the muscular tissue of the abdomen $(\mathrm{AB})$ reflects mainly the phospholipid composition of bio-membranes with low levels of lipid reserves (Albessard et al. 2001). M. norvegica accumulates neutral lipids, principally triacylglycerol (TAG), with a strong seasonal pattern reflecting changes in trophic conditions (Buchholz \& Prado-Fiedler 1987, Mayzaud et al. 1999) coupled with gonad maturation (Falk-Petersen et al. 1981, Cuzin-Roudy et al. 1999). In addition to TAG, phosphatidylcholine (PC) is actively stored in the ovary during egg maturation indicating that it plays an important role during reproduction (Albessard et al. 2001). With respect to membrane lipids, differential synthesis of specific phospholipids in crustaceans can occur in response to changes in environmental temperature and salinity (Chapelle 1986). Thus, the comparative study of polar lipid distribution in a membrane-rich tissue such as the abdomen between populations of Meganyctiphanes norvegica living at different temperature and salinity could provide new insights into the potential adaptation of this species.
Lipid-class composition in both the cephalothorax and abdomen of Meganyctiphanes norvegica were analysed for 3 different locations: the Ligurian Sea, the Clyde Sea and the Kattegat. Particular attention was given to the coupling of trophic conditions with reproductive needs in connection with temperature and salinity.

\section{MATERIALS AND METHODS}

Sampling. Individuals of Meganyctiphanes norvegica (M. Sars, 1857) were collected using an I-KMT net (Isaacs \& Kidd 1953), a MOCNESS net (Wiebe et al. 1976) or a $2 \mathrm{~m}^{2}$ ring net (all nets of $2 \mathrm{~mm}$ mesh). Sampling was made during cruises in 1996-1997: in July and February in the Clyde Sea, in July and March in the Kattegat and in April and September in the Ligurian Sea. Identification of the species was verified for the 3 sites by euphausiids specialists (Dr. J. CuzinRoudy, Dr. J. Matthews \& Dr. F. Buchholz). In addition, genetic authentication of the species at the 3 sites was made by Zane et al. (2000). Location, sampling parameters, temperature and salinity were measured throughout the sampling period (Table 1). Directly after collection, female krill were sorted into various sexual development stages (Cuzin-Roudy \& Buchholz 1999). Krill from February (Clyde Sea) and September (Ligurian Sea) were at sexual rest. In the Kattegat in March, males were already mature, but females were still at sexual rest. Krill from July (Clyde Sea, Kattegat) or April (Ligurian Sea) were actively reproducing. Females were staged as vitellogenic, ready to spawn or postspawn. They were rinsed with distilled water and then snap-frozen in liquid nitrogen and stored at $-80^{\circ} \mathrm{C}$ until analysis (within a few months). Using either a WP II net (200 $\mu \mathrm{m}$ mesh) or a MOCNESS (300 $\mu \mathrm{m}$ mesh), additional vertical or horizontal tows were made from $200 \mathrm{~m}$ to the surface (depending on the depth of the bottom) to collect mesozooplankton. Sampling was carried out to compare the reproductive/high-food period with the non-reproductive low-food period and not to record the entire seasonal variability at each site. Water samples were collected at different depths with a 121 Niskin bottle. Water was prefiltered on $200 \mu \mathrm{m}$ bolting cloth, and a known volume was filtered through GF/F Whatman filters. Filters were extracted in $90 \%$ acetone for $24 \mathrm{~h}$ at $4^{\circ} \mathrm{C}$. Chlorophyll a (chl a) and phaeopigments were analysed by fluorometry according to the method of Holm-Hansen et al. (1965).

Chlorophyll content of gut and feeding experiments. Adult krill were sexed under dim light, measured, dissected to retrieve the $\mathrm{CT}$, homogenised in $90 \%$ acetone with a Potter homogeniser, and extracted for $4 \mathrm{~h}$ in darkness in the refrigerator. Samples were then centrifuged 
at $3000 \mathrm{rpm}$ for $15 \mathrm{~min}$. Fluorescence before and after acidification were measured according to Dagg \& Walser (1987) with a Model 10 Turner Design fluorometer. Fluorescence background levels of tissues were considered to be negligible. Gut-pigment contents were calculated as the sum of chl $a$ and the phaeopigments. Usually 10 to 15 krill were used for each determination.

Feeding experiments used increasing densities of assemblages of Temora longicornis, with a few Pseudocalanus spp. in summer and Pseudocalanus spp./ Paracalanus spp. in winter in the Clyde Sea. Stages CIII to CIV of Calanus spp. were used in the Kattegat. A stock population was sorted under a binocular microscope and diluted to achieve the desired concentration. Individual adult krill were placed in 21 jars filled with filtered seawater (0.45 $\mu \mathrm{m}$ Millipore filters). A known number of copepods were added, and for each copepod density a jar without krill was used as control. All incubations took place at in situ (middepth) temperatures in darkness for $15 \mathrm{~h}$. At the end of incubation, euphausiids were removed and measured. Copepods were concentrated and preserved in $5 \%$ formalin until counted a few months later. The chl $a$ and zooplankton ingestion rates are shown in Table 1.

Dissection, size, weight measurements and lipid extraction. Krill were placed frozen on ice blocks $\left(-18^{\circ} \mathrm{C}\right)$, covered with absorbent paper, and brought to $0^{\circ} \mathrm{C}$. Directly after body length (BL) and body fresh weight (BWW) determinations, the krill were rapidly re-frozen in liquid nitrogen and dissected to separate the $\mathrm{CT}$ from the $\mathrm{AB}$. The $\mathrm{CT}$ and $\mathrm{AB}$ were then quickly weighed while still frozen to avoid any condensation and loss of fluids (loss was less than $5 \%$ in all cases).
The CT and AB were extracted separately in chloroform methanol water $(2: 2: 1.8, \mathrm{v}: \mathrm{v}: \mathrm{v})$ following the method of Bligh \& Dyer (1959). Lipid extracts were weighed after solvent evaporation under high vacuum (15 min at $30 \mathrm{~mm} \mathrm{Hg}$ ) in tared glass vials sealed with Teflon gasket caps, and were then stored at $-80^{\circ} \mathrm{C}$ under $\mathrm{N}_{2}$ until lipid analyses.

Lipid analyses. Lipid classes were quantified after chromatographic separation coupled with flame ionization detection on an Iatroscan Mark III TH 10 (Ackman 1981). Lipid samples were applied with microcapillaries (Drumond) of $1 \mu \mathrm{l}$ on Chromarods SIII (Iatron, Japan) and analysed in duplicate. Quantification of the major lipid compounds was achieved after calibration of the chromarods with triacylglycerol (TAG), phosphatidylcholine (PC) and phosphatidylethanolamine (PE) of Meganyctiphanes norvegica previously purified by column chromatography and preparative thin-layer chromatography (Mayzaud et al. 2000). Standards of analytical grade (Sigma) were used for the calibration of other lipid classes. Neutral lipids were separated using a double development procedure with the following solvent systems: n-hexane:benzene:formic acid (80:20:1, v:v:v) followed by n-hexane:diethylether: formic acid (97:3:1, v:v:v). Polar lipids of the total lipid extract were separated in methanol:chloroform: ammonium hydroxide $27.3 \%$ (50:50:5, v:v:v) after initial development in benzene:chloroform:formic acid (50:20:1.5, v:v:v), and were partially scanned to eliminate neutral lipids (Angelo \& James 1993). Free fatty acids always comprised $<1 \%$ of the total lipid classes.

Statistical analysis. Allometric relationships between body wet weight and body length $\left(\mathrm{BWW}=a \times \mathrm{BL}^{b}\right)$ and

Table 1. Meganyctiphanes norvegica. Study areas, seasons, locations, sampling parameters (Time, Depth, Latitude, Longitude), environmental parameters (P. Mayzaud et al. unpubl. data: temperature, chl a concentration, zooplankton density) and nutritional parameters (chl a ingestion, copepod ingestion). DW: dry weight (mg); C: carbon

\begin{tabular}{|c|c|c|c|c|c|c|}
\hline & \multicolumn{2}{|c|}{$\longrightarrow$ Ligurian Sea } & \multicolumn{2}{|c|}{ Clyde Sea } & \multicolumn{2}{|c|}{ —Kattegat (Læsø Deep) - } \\
\hline & Spring & Fall & Summer & Winter & Summer & Winter \\
\hline Date (dd/mm/yy) & $10-27 / 04 / 96$ & $8-21 / 09 / 97$ & 04/07/96 & $17-26 / 02 / 97$ & $17-19 / 07 / 96$ & 09/03/97 \\
\hline Time ( $\mathrm{h}$, local time) & $00-03.5$ & $22.5-23$ & 02 & $11.3 / 22.5$ & $15.5 / 17.5 / 20$ & $15.5-16$ \\
\hline Depth (m) & $0-65$ & $25-80$ & $25-50$ & $0-150$ & $75-100$ & $80-95$ \\
\hline Latitude & $43^{\circ} 14^{\prime}-25^{\prime}$ & $43^{\circ} 19^{\prime}$ & $55^{\circ} 40^{\prime}$ & $55^{\circ} 42^{\prime}-55^{\prime}$ & $57^{\circ} 18^{\prime}$ & $57^{\circ} 18^{\prime}$ \\
\hline Longitude & $7^{\circ} 41^{\prime}-8^{\circ} 32^{\prime}$ & $7^{\circ} 51^{\prime}$ & $5^{\circ} 04^{\prime}$ & $5^{\circ} 09^{\prime}-5^{\circ} 23^{\prime}$ & $11^{\circ} 26^{\prime}$ & $11^{\circ} 26^{\prime}$ \\
\hline $\mathrm{T}\left({ }^{\circ} \mathrm{C}\right)$ & 13 & 13 & $8.5-11$ & 7 & 6 & $3-4$ \\
\hline Chl a $\left(\mu g \mathrm{l}^{-1}\right)$ & $1.5-5$ & $0.5-2$ & $12-15$ & 1 & $1-1.2$ & $1-2$ \\
\hline $\begin{array}{l}\text { Zooplankton density } \\
\quad\left(\mathrm{mg} \mathrm{DW} \mathrm{m}^{-3}\right)\end{array}$ & $6.8 \times 10^{-3}$ & $6.3 \times 10^{-4}$ & 5.04 & 0.59 & 15.1 & 18.7 \\
\hline $\begin{array}{l}\text { Chl a ingestion } \\
\qquad\left(\mathrm{mg} \mathrm{C} \mathrm{d}^{-1}\right)\end{array}$ & 0.04 & 0.03 & 3.91 & 0.04 & 0.06 & 0.64 \\
\hline $\begin{array}{l}\text { Copepod ingestion } \\
\left(\mathrm{mg} \mathrm{C} \mathrm{d}^{-1}\right)\end{array}$ & 0.24 & 0.33 & 0 & 0.43 & 1.1 & 0.64 \\
\hline$\Sigma$ ingestion & 0.28 & 0.36 & 3.9 & 0.47 & 1.1 & 1.3 \\
\hline
\end{tabular}


lipid content (LC) ( $\mathrm{LC}=a \times \mathrm{WW}^{b}$ ) were computed for the 3 sites after log-log transformation. Model 1 and Model 2 regressions were used to calculate the allometric coefficient. Model 1 regression is commonly used, but Model 2 is better able to express the relationship between 2 covarying variables (Cuzin-Roudy 2000). A non-parametric Mann-Whitney $U$-test was performed for pairwise comparisons of lipid content and lipid class data. All statistics followed the method of Sokal \& Rohlf (1981). Systat 7.0 statistical software was used for all bivariate tests (Wilkinson 1996).

Principal component analyses (PCA) following Legendre \& Legendre (1984), and Lebart et al. (1995) were performed on the correlation matrix of lipid distribution ( $\mathrm{mg} \mathrm{mg}^{-1}$ organ wet weight) in either the CT or $\mathrm{AB}$ for the different groups of krill from the 3 sites. PCA was used to establish the major (or principal) characteristics of a set of variables observed in a set of samples and to give a graphical representation of their similarities in a reduced dimensional factorial space. Once the factorial axes based on active variables have been extracted, supplementary or illustrative variables (total lipid content and chl $a$ as trophic descriptor) not used in the determination of the axes may be added to the analysis. These may be located by projecting them onto the factorial plans derived from the active variable only. As a second step, an hierarchical clustering analysis (HCA) was performed between the different groups of krill described by their component scores on the first 5 axes of the PCA using the Ward agglomeration method (Ward 1963). This clustering offers the possibility of representing the distances between groups of krill by a dendogram. Because lipid distribution of males and females were similar during the non-reproductive season (September and February/March) for all 3 sites, they were pooled within a single group. PCA and HCA were computed using SPAD 3.0 software (Lebart et al. 1995).

\section{RESULTS}

\section{Environmental and nutritional characteristics}

Major differences in chl a concentrations were observed in July/April, with high levels in the Clyde Sea (12 to $\left.15 \mu \mathrm{g} \mathrm{l}^{-1}\right)$, and low concentrations in the Kattegat $\left(1 \mathrm{\mu g}^{-1}\right)$ (Table 1$)$. The Ligurian Sea displayed intermediate values (1.5 to $5 \mathrm{\mu g} \mathrm{l}^{-1}$ ) depending on sampling location. At all 3 locations, chl a concentration was low in February, March and September. Zooplankton density was generally high in the Kattegat (15 to $19 \mathrm{mg}$ dry wt $\mathrm{m}^{-3}$ ), in contrast to very low values recorded in the Ligurian Sea $\left(6 \times 10^{-4}\right.$ to $6 \times 10^{-3} \mathrm{mg}$ dry $\mathrm{wt} \mathrm{m}^{-3}$ ). Intermediate densities were measured in summer in the Clyde ( 0.6 to $5 \mathrm{mg}$ dry wt $\mathrm{m}^{-3}$ ). Chl $a$ inges- tion and copepod ingestion rates (Table 1) indicated strong seasonal differences in summer in the Clyde Sea, with higher selective feeding on phytoplankton. In the Kattegat, total ingestion rates were in the same range in summer and winter, with the diet consisting almost exclusively of copepods in summer and of equal proportions of phytoplankton and copepods in winter. In the Ligurian Sea, krill fed mainly on zooplankton at low ingestion rates regardless of season.

\section{Size, weight and lipid content relationships}

Allometric relationships between BWW and BL were established for different seasons for each krill population (Table 2). The Model 1 log-log regressions between size and weight were significant for all 3 sites. A better fit to the data was obtained with the Model 2 regression (reduced major axis). The regression coefficient ' $b$ Mod-2' was higher than ' $b$ Mod- 1 ' when $\mathrm{R}$ was $<1$ (Table 2). With ' $b$ Mod-2', the relationship BWW/BL indicated isometry ( $b=3$ for weight/length relationship) for krill in the Ligurian Sea and in the Kattegat in July. In contrast, the weight increase with increasing body size was less in March in the Kattegat and in the Clyde Sea during both months (Table 2). For the 3 locations in July and April, krill in the Clyde were larger (Table 3) and increased less in weight than krill in the other 2 populations. With respect to lipid content, the LC/BWW regressions were significant for all 3 populations, but only $12 \%$ of the variance was explained by Model 1 regression for the Ligurian population (Table 2). With ' $b$ Mod-2', the relationship LC/BWW in the Kattegat was isometric ( $b=1$, for a weight/weight relationship), while in the Clyde Sea, the LC increased at a higher rate than that for BWW $(b>1)$.

\section{Total lipid content in cephalothorax and abdomen}

The total lipid content, in absolute (mg) and relative (\% wet weight) terms, of the $\mathrm{CT}$ and $\mathrm{AB}$ as well as the $\mathrm{CT}$ :AB lipid ratio of krill from the 3 locations are presented in Table 3. The CT is the main lipid storage site, with 2 to 4 times higher contents than the AB. The lipid content of $C T$, and to a lesser extent of $A B$, showed variations as a function of season, reproductive status and location.

\section{Seasonal and geographical variation in total lipid content: influence of trophic conditions}

In the Ligurian Sea, male and vitellogenic and readyto-spawn female krill displayed higher lipid levels in 
April than in September both in the CT and AB (p < 0.05 in all cases), although the lipid allocation between the 2 body compartments (ratio $\mathrm{R}_{\mathrm{CT}: \mathrm{AB}}$ ) did not differ. In April and September, lipid content varied as a function of variations in trophic conditions (chl $a$ and zooplankton density) between these 2 months (Table 1). In the Clyde Sea, males did not show any significant difference in lipid content between July and February, either in absolute or in relative terms, mainly due to the highly variable CT lipid content in July. As in the Ligurian Sea, ready-to-spawn females in July displayed higher lipid levels than females at sexual rest in February, both in the CT and the $\mathrm{AB}\left(\mathrm{CT}: U_{\mathrm{mg} ; 11,10}=0\right.$; $U_{\% w_{i} ; 1,10}=7 ;$ AB: $\left.U_{\mathrm{mg}_{i} 11,10}=7 ; U_{\% w_{i} 11,10}=17\right)$. Despite the great variability in lipid content in July, a general trend of lipid accumulation in the CT corresponded to the greater concentration of potential food sources in this month (Table 1). In the Kattegat, a reverse seasonal pattern of lipid storage was evident: in March the krill lipid content was higher in relative terms than in July in the $C T$ and the $A B(p<0.05$ in all cases), with a greater allocation of lipids in the male $C T\left(\mathrm{R}_{\mathrm{CT}: A B}\right.$ : $U_{10,10}=19$ ). During the period of sexual rest in the Ligurian and Clyde Seas and at the onset of the reproduction period in the Kattegat, the relative lipid content of the $\mathrm{CT}$ of males and the $\mathrm{AB}$ of females followed the order: Ligurian Sea $<$ Clyde Sea $<$ Kattegat $(\mathrm{p}<$ 0.05 in all cases). For reproductive krill the lipid content in males followed the order: Kattegat = Ligurian Sea $<$ Clyde Sea. Reproducing females also displayed a gradient of lipid content ( $C T, A B)$, with higher content in the Clyde Sea followed by the Ligurian Sea and the Kattegat ( $p<0.05$ in all cases). Very low lipid allocation to the CT was recorded in the Kattegat population, while a high lipid allocation to the CT was characteris- tic of Clyde krill (especially ready-to-spawn females): $\mathrm{R}_{\mathrm{CT}: \mathrm{AB}}$, Kattegat-Ligurian: $U_{50,60}=640$; Ligurian-Clyde: $U_{60,31}=1408$.

\section{Variation in total lipid content among reproductive stages}

During the reproductive period (April/July), males and ready-to-spawn females from the 3 locations did not show significant differences in lipid content (Table 3). The Ligurian population displayed the most marked characteristics with regard to lipid allocation for reproduction. Vitellogenic and ready-to-spawn females had significantly higher lipid contents in their $\mathrm{CT}$ and $\mathrm{AB}$ than postspawn females both in absolute and relative terms $(\mathrm{p}<0.05$ in all cases), with a higher lipid allocation $\left(\mathrm{R}_{\mathrm{CT}: \mathrm{AB}}\right)$ to the $\mathrm{CT}$ (vitellogenicpostspawn: $U_{20,18}=266$; ready-to-spawn-postspawn: $\left.U_{12,18}=187\right)$. These differences indicate a large lipid accumulation for egg production followed by a loss of $55 \%$ of total lipids in the CT after spawning. Moreover, there was a significant increase in the lipid content between the vitellogenic and ready-to-spawn stages of females corresponding to the allocation of lipid to the eggs through vitellogenesis (\%WW; CT: $U_{12,20}=66$; AB: $U_{12,20}=61$ ). Despite the high intra-group variability in the lipid content of krill from the Clyde population, differences between ready-to-spawn and postspawn females in the $\mathrm{CT}$ were significant in absolute and relative terms (mg: $U_{6,11}=55 ; \% \mathrm{WW}$ : $U_{6,11}=61$ ), with greater lipid allocation to ready-tospawn females $\left(\mathrm{R}_{\mathrm{CT}: \mathrm{AB}}: U_{6,11}=55\right)$ and a loss of $33 \%$ of CT lipids through spawning. In the Kattegat, lipid allocation to reproduction in females was very low leading

Table 2. Meganyctiphanes norvegica. Log-log linear regressions between body wet weight (BWW) and body length (BL) and between body lipid content (LC) and body wet weight for the 3 krill populations. N: number of krill; $b$ : coefficient of allometry obtained with Model 1 (Mod-1) and Model 2 (Mod-2) regressions; $b$ SE: standard error of $b$ (Models 1 and 2); CI $b$ (95\%): $95 \%$ confidence interval of $b$. The $\mathrm{r}^{2}$ and ANOVA $F$ ratio are given for Model 1 regression. ${ }^{*} \mathrm{p}<0.01 ;{ }^{* *} \mathrm{p}<0.001$

\begin{tabular}{|c|c|c|c|c|c|c|c|c|c|}
\hline \multicolumn{2}{|c|}{ Allometric relationship } & $\mathrm{N}$ & $b$ Mod-1 & $b \mathrm{SE}$ & CI $b(95 \%)$ & a & $\mathrm{r}^{2}$ & ANOVA F ratio & $b$ Mod-2 \\
\hline \multicolumn{10}{|c|}{$\log B W W=b \times \log B L+a$} \\
\hline \multirow[t]{2}{*}{ Ligurian Sea } & April & 62 & 2.75 & 0.15 & $2.45-3.06$ & -1.71 & 0.85 & $333^{* *}$ & 2.99 \\
\hline & September & 20 & 2.24 & 0.42 & $1.35-3.12$ & -0.94 & 0.61 & $28^{* *}$ & 2.86 \\
\hline \multirow{2}{*}{ Kattegat } & July & 50 & 2.93 & 0.13 & $2.67-3.18$ & -1.99 & 0.92 & $533^{* *}$ & 3.06 \\
\hline & March & 20 & 1.58 & 0.33 & $0.89-2.28$ & -0.06 & 0.56 & $23^{* *}$ & 2.11 \\
\hline \multirow[t]{2}{*}{ Clyde Sea } & July & 31 & 2.21 & 0.19 & $1.81-2.6$ & -0.88 & 0.82 & $132^{* *}$ & 2.44 \\
\hline & February & 20 & 1.96 & 0.27 & $1.4-2.53$ & -0.49 & 0.75 & $53^{* *}$ & 2.27 \\
\hline \multicolumn{10}{|c|}{$\log \mathrm{LC}=b \times \log \mathrm{BWW}+a$} \\
\hline \multicolumn{2}{|c|}{ Ligurian Sea } & 81 & 0.68 & 0.20 & $0.28-1.09$ & -0.77 & 0.12 & $11^{*}$ & 1.94 \\
\hline \multicolumn{2}{|l|}{ Kattegat } & 70 & 0.91 & 0.11 & $0.68-1.14$ & -1.37 & 0.48 & $63^{* *}$ & 1.31 \\
\hline \multicolumn{2}{|l|}{ Clyde Sea } & 48 & 1.57 & 0.21 & $1.14-1.99$ & -2.87 & 0.54 & $55^{* *}$ & 2.13 \\
\hline
\end{tabular}


Table 3. Meganyctiphanes norvegica. Lipid content of cephalotorax and abdomen and mean body length of males and females from Ligurian Sea, Clyde Sea and Kattegat as both absolute (mg) and relative (\% wet weight). N: number of samples; $R_{C T: A B}$ : ratio between cephalothorax and abdomen lipid content

\begin{tabular}{|c|c|c|c|c|c|c|}
\hline & & Cephalothorax & Abdomen & $\mathrm{R}_{\mathrm{CT}: \mathrm{AB}}$ & Body length (mm) & $\mathrm{N}$ \\
\hline \multicolumn{7}{|l|}{ Ligurian Sea } \\
\hline \multicolumn{7}{|l|}{ April } \\
\hline \multirow[t]{2}{*}{ Males mature } & $\% W W$ & $5.8 \pm 1.2$ & $2.1 \pm 0.4$ & $2.8 \pm 0.6$ & $28.9 \pm 1.0$ & 10 \\
\hline & $\mathrm{mg}$ & $5.4 \pm 1.1$ & $2.1 \pm 0.4$ & & & \\
\hline \multirow[t]{2}{*}{ Females vitellogenic } & $\% W W$ & $5.5 \pm 1.6$ & $2.3 \pm 0.4$ & $2.4 \pm 0.5$ & $30.5 \pm 1.7$ & 20 \\
\hline & $\mathrm{mg}$ & $6.9 \pm 1.8$ & $2.7 \pm 0.5$ & & & \\
\hline \multirow[t]{2}{*}{ spawning } & $\% W W$ & $6.9 \pm 1.9$ & $2.6 \pm 0.4$ & $2.6 \pm 0.5$ & $31.7 \pm 2.2$ & 12 \\
\hline & $\mathrm{mg}$ & $9.8 \pm 2.1$ & $3.5 \pm 0.8$ & & & \\
\hline \multirow{2}{*}{ postspawn } & $\% W W$ & $3.1 \pm 0.7$ & $1.6 \pm 0.4$ & $2.0 \pm 0.3$ & $29.7 \pm 1.8$ & 20 \\
\hline & $\mathrm{mg}$ & $3.6 \pm 1.1$ & $1.6 \pm 0.4$ & & & \\
\hline \multicolumn{7}{|l|}{ September } \\
\hline \multirow[t]{2}{*}{ Males sexual rest } & $\% W W$ & $4.1 \pm 2.0$ & $1.6 \pm 0.4$ & $2.5 \pm 0.8$ & $32.8 \pm 0.8$ & 10 \\
\hline & $\mathrm{mg}$ & $5.3 \pm 2.4$ & $2.4 \pm 0.6$ & & & \\
\hline \multirow{2}{*}{ Females sexual rest } & $\% W W$ & $3.9 \pm 1.8$ & $1.5 \pm 0.2$ & $2.6 \pm 0.9$ & $32.2 \pm 1.1$ & 10 \\
\hline & $\mathrm{mg}$ & $5.2 \pm 2.6$ & $2.1 \pm 0.5$ & & & \\
\hline \multicolumn{7}{|l|}{ Clyde Sea } \\
\hline \multicolumn{7}{|l|}{ July } \\
\hline \multirow{2}{*}{ Males mature } & $\% \mathrm{WW}$ & $8.2 \pm 3.0$ & $2.1 \pm 0.5$ & $4.0 \pm 1.2$ & $40.1 \pm 2.4$ & 6 \\
\hline & $\mathrm{mg}$ & $14.4 \pm 5.5$ & $4.8 \pm 1.3$ & & & \\
\hline \multirow[t]{2}{*}{ Females vitellogenic } & $\% W W$ & $7.4 \pm 4.4$ & $2.2 \pm 0.2$ & $3.2 \pm 1.7$ & $39.2 \pm 0.5$ & 6 \\
\hline & $\mathrm{mg}$ & $16.2 \pm 10.3$ & $4.7 \pm 0.7$ & & & \\
\hline \multirow[t]{2}{*}{ spawning } & $\% W W$ & $9.0 \pm 2.4$ & $2.3 \pm 0.2$ & $4.0 \pm 1.0$ & $38.8 \pm 3.2$ & 11 \\
\hline & $\mathrm{mg}$ & $20.1 \pm 6.6$ & $4.7 \pm 0.8$ & & & \\
\hline \multirow{2}{*}{ postspawn } & $\% W W$ & $6.0 \pm 1.2$ & $2.1 \pm 0.2$ & $2.9 \pm 0.7$ & $38.0 \pm 3.2$ & 6 \\
\hline & $\mathrm{mg}$ & $13.1 \pm 4.7$ & $4.3 \pm 0.9$ & & & \\
\hline \multicolumn{7}{|l|}{ February } \\
\hline \multirow[t]{2}{*}{ Males sexual rest } & $\% W W$ & $5.6 \pm 0.7$ & $2.0 \pm 0.3$ & $3.0 \pm 0.6$ & $37.7 \pm 1.4$ & 10 \\
\hline & $\mathrm{mg}$ & $10.2 \pm 1.7$ & $4.3 \pm 0.5$ & & & \\
\hline \multirow[t]{2}{*}{ Females sexual rest } & $\% W W$ & $5.1 \pm 1.8$ & $1.8 \pm 0.3$ & $2.8 \pm 0.7$ & $34.8 \pm 2.7$ & 10 \\
\hline & $\mathrm{mg}$ & $7.3 \pm 2.5$ & $3.2 \pm 0.5$ & & & \\
\hline \multicolumn{7}{|l|}{ Kattegat } \\
\hline \multicolumn{7}{|l|}{ July } \\
\hline \multirow[t]{2}{*}{ males mature } & $\% W W$ & $3.3 \pm 0.9$ & $1.5 \pm 0.4$ & $2.4 \pm 0.9$ & $33.8 \pm 1.5$ & 10 \\
\hline & $\mathrm{mg}$ & $4.6 \pm 1.4$ & $2.4 \pm 0.7$ & & & \\
\hline \multirow[t]{2}{*}{ Females vitellogenic } & $\% W W$ & $2.8 \pm 0.5$ & $1.6 \pm 0.3$ & $1.7 \pm 0.3$ & $28.8 \pm 1.4$ & 10 \\
\hline & $\mathrm{mg}$ & $2.8 \pm 0.6$ & $1.5 \pm 0.3$ & & & \\
\hline \multirow[t]{2}{*}{ spawning } & $\% W W$ & $3.2 \pm 0.4$ & $1.6 \pm 0.3$ & $2.0 \pm 0.2$ & $30.3 \pm 2.1$ & 10 \\
\hline & $\mathrm{mg}$ & $3.9 \pm 0.8$ & $1.7 \pm 0.4$ & & & \\
\hline postspawn & $\% W W$ & $3.0 \pm 0.4$ & $1.8 \pm 0.4$ & $1.7 \pm 0.2$ & $31.0 \pm 2.7$ & 20 \\
\hline & $\mathrm{mg}$ & $3.8 \pm 1.2$ & $2.0 \pm 0.5$ & & & \\
\hline March & & & & & & \\
\hline Males sexual rest & $\% W W$ & $6.5 \pm 2.3$ & $1.9 \pm 0.4$ & $3.6 \pm 1.3$ & $31.9 \pm 4.8$ & 10 \\
\hline & $\mathrm{mg}$ & $6.9 \pm 3.8$ & $2.5 \pm 0.8$ & & & \\
\hline Females sexual rest & $\% W W$ & $4.1 \pm 0.9$ & $2.2 \pm 0.3$ & $1.9 \pm 0.5$ & $30.7 \pm 3.7$ & 10 \\
\hline & $\mathrm{mg}$ & $3.5 \pm 1.5$ & $2.1 \pm 0.4$ & & & \\
\hline
\end{tabular}

to very few differences between maturing and postspawn females.

\section{Lipid-class distribution in cephalothorax and abdomen}

The lipid class composition (\% wet weight) of Meganyctiphanes norvegica for the 3 populations is presented in Tables 4 to 6 . Some features were com- mon to all 3 sites. As anticipated, the $\mathrm{CT}$ is the main storage organ for all lipids classes. The AB, mostly constituted of muscular tissue, is not a primary location for lipid accumulation, and lipid distribution was similar among groups of krill at the same reproductive period. The lipid structure in the AB reflects mainly the composition of the phospholipids in biomembranes with a low TAG content. The main phospholipids were PC, followed by $\mathrm{PE}$ and the unresolved phosphatidylserine, -inositol (PS-PI) compounds. Unresolved phos- 
phatidyl-, diphosphatidylglycerol (PG-DPG) and lysophosphatidylcholine (LPC) were minor contributors.

\section{The Ligurian population}

The CT (Table 4) contained higher proportions of diacylglycerol (DAG), PC, LPC and PG-DPG in April than in September ( $p<0.05$ in all cases). TAG levels for spring-reproducing krills were higher than in autumn, although the differences were not significant. In the $\mathrm{AB}$, krill in April displayed higher levels of all lipid compounds than in September ( $p<0.05$ in all cases) with the exception of PS-PI. Reproductive krill displayed significant differences in their lipid distributions, especially between different sexual development stages of females. Ready-to-spawn females had higher levels of DAG and PS-PI ( $p<0.05)$ than other females and males in both the $\mathrm{CT}$ and $\mathrm{AB}$. Conversely they contained less cholesterol and PG-DPG in the CT than males and vitellogenic females $(p<0.001)$. In comparison to ready-to-spawn females, postspawn females had lower levels of TAG as well as of major phospholipids (PC, PE, PS-PI) in their CT ( $p<0.05)$, in accordance with the loss of major lipids during spawning.

\section{Clyde population}

The Clyde population of Meganyctiphanes norvegica displayed a strong seasonal pattern in lipid distribution. Reproductive krill in July contained 2 times more TAG $\left(U_{20,31}=400\right)$ and PC $\left(U_{20,31}=544\right)$ in their CT than in February (Table 5). Conversely, phospholipids such as PG-DPG $\left(U_{20,31}=38\right)$, PE $\left(U_{20,31}=64\right)$ and neutral lipids such as DAG $\left(U_{20,31}=34\right)$ and cholesterol $\left(U_{20,31}=62\right)$ levels were significantly lower in the CT in July by a factor of 2 to 4, while LPC and PS-PI did not show any significant differences either in the $\mathrm{CT}$ or the $\mathrm{AB}$. In the $\mathrm{AB}$, seasonal differences in lipid proportions occurred in

Table 4. Meganyctiphanes norvegica. Lipid-class distribution in cephalothorax and abdomen of krill from the Ligurian Sea expressed as \% wet weight. Data are means (SD). DAG: diacylglycerol; TAG = triacylglycerol; Chol.: cholesterol; PC: phosphatidylcholine; LPC = lysophosphatidylcholine; PG-DPG: phosphatidyl-; diphosphatidylglycerol; $\mathrm{PE}=$ phosphatidylethanolamine; PS-PI: phosphatidyl-serine, -inositol

\begin{tabular}{|c|c|c|c|c|c|c|c|c|}
\hline & DAG & TAG & Chol. & PC & LPC & PG-DPG & $\mathrm{PE}$ & PS-PI \\
\hline \multicolumn{9}{|l|}{ Cephalothorax } \\
\hline \multicolumn{9}{|l|}{ April } \\
\hline \multirow[t]{2}{*}{ Males mature } & 0.24 & 2.37 & 0.51 & 1.70 & 0.14 & 0.10 & 0.32 & 0.19 \\
\hline & $(0.07)$ & $(0.78)$ & $(0.11)$ & $(0.35)$ & $(0.06)$ & $(0.01)$ & $(0.05)$ & $(0.03)$ \\
\hline \multirow[t]{2}{*}{ Females vitellogenic } & 0.27 & 2.15 & 0.32 & 1.98 & 0.05 & 0.09 & 0.35 & 0.19 \\
\hline & $(0.16)$ & $(0.91)$ & $(0.12)$ & $(0.48)$ & $(0.02)$ & $(0.03)$ & $(0.08)$ & $(0.04)$ \\
\hline \multirow[t]{2}{*}{ spawning } & 0.54 & 3.00 & 0.17 & 1.68 & 0.14 & 0.05 & 0.45 & 0.51 \\
\hline & $(0.11)$ & $(1.23)$ & $(0.07)$ & $(0.42)$ & $(0.08)$ & $(0.04)$ & $(0.21)$ & $(0.13)$ \\
\hline \multirow[t]{2}{*}{ postspawn } & 0.20 & 0.67 & 0.20 & 1.25 & 0.04 & 0.09 & 0.27 & 0.17 \\
\hline & $(0.08)$ & $(0.39)$ & $(0.06)$ & $(0.30)$ & $(0.01)$ & $(0.03)$ & $(0.04)$ & $(0.03)$ \\
\hline \multicolumn{9}{|l|}{ September } \\
\hline Males sexual rest & $\begin{array}{c}0.21 \\
(0.14)\end{array}$ & $\begin{array}{c}1.84 \\
(1.59)\end{array}$ & $\begin{array}{c}0.24 \\
(0.15)\end{array}$ & $\begin{array}{c}1.16 \\
(0.34)\end{array}$ & $\begin{array}{c}0.04 \\
(0.02)\end{array}$ & $\begin{array}{c}0.06 \\
(0.02)\end{array}$ & $\begin{array}{c}0.25 \\
(0.08)\end{array}$ & $\begin{array}{c}0.23 \\
(0.09)\end{array}$ \\
\hline Females sexual rest & $\begin{array}{c}0.14 \\
(0.07)\end{array}$ & $\begin{array}{c}1.59 \\
(1.08)\end{array}$ & $\begin{array}{c}0.24 \\
(0.07)\end{array}$ & $\begin{array}{c}1.34 \\
(0.40)\end{array}$ & $\begin{array}{c}0.07 \\
(0.04)\end{array}$ & $\begin{array}{c}0.05 \\
(0.03)\end{array}$ & $\begin{array}{c}0.42 \\
(0.13)\end{array}$ & $\begin{array}{c}0.22 \\
(0.07)\end{array}$ \\
\hline \multicolumn{9}{|l|}{ Abdomen } \\
\hline \multicolumn{9}{|l|}{ April } \\
\hline \multirow[t]{2}{*}{ Males mature } & 0.09 & 0.34 & 0.14 & 1.02 & 0.04 & 0.06 & 0.18 & 0.09 \\
\hline & $(0.02)$ & $(0.12)$ & $(0.03)$ & $(0.24)$ & $(0.03)$ & $(0.01)$ & $(0.02)$ & $(0.01)$ \\
\hline \multirow[t]{2}{*}{ Females vitellogenic } & 0.11 & 0.42 & 0.13 & 1.13 & 0.04 & 0.07 & 0.20 & 0.11 \\
\hline & $(0.05)$ & $(0.12)$ & $(0.02)$ & $(0.19)$ & $(0.02)$ & $(0.02)$ & $(0.05)$ & $(0.03)$ \\
\hline \multirow[t]{2}{*}{ spawning } & 0.20 & 0.56 & 0.13 & 0.98 & 0.06 & 0.04 & 0.14 & 0.52 \\
\hline & $(0.06)$ & $(0.21)$ & $(0.04)$ & $(0.15)$ & $(0.02)$ & $(0.03)$ & $(0.09)$ & $(0.25)$ \\
\hline \multirow[t]{2}{*}{ postspawn } & 0.10 & 0.24 & 0.09 & 0.74 & 0.02 & 0.06 & 0.16 & 0.09 \\
\hline & $(0.02)$ & $(0.13)$ & $(0.02)$ & $(0.23)$ & $(0.01)$ & $(0.01)$ & $(0.03)$ & $(0.02)$ \\
\hline \multicolumn{9}{|l|}{ September } \\
\hline \multirow[t]{2}{*}{ Males sexual rest } & 0.07 & 0.27 & 0.10 & 0.76 & 0.02 & 0.05 & 0.15 & 0.12 \\
\hline & $(0.02)$ & $(0.14)$ & $(0.01)$ & $(0.19)$ & $(0.01)$ & $(0.03)$ & $(0.08)$ & $(0.04)$ \\
\hline \multirow[t]{2}{*}{ Females sexual rest } & 0.05 & 0.21 & 0.09 & 0.81 & 0.02 & 0.05 & 0.12 & 0.10 \\
\hline & $(0.01)$ & $(0.08)$ & $(0.02)$ & $(0.14)$ & $(0.02)$ & $(0.01)$ & $(0.02)$ & $(0.02)$ \\
\hline
\end{tabular}


Table 5. Meganyctiphanes norvegica. Lipid-class distribution in cephalothorax and abdomen of krill from the Clyde Sea expressed as \% of wet weight. Data are means (SD). Abbreviations as in Table 4

\begin{tabular}{|c|c|c|c|c|c|c|c|c|}
\hline & DAG & TAG & Chol. & $\mathrm{PC}$ & LPC & PG-DPG & $\mathrm{PE}$ & PS-PI \\
\hline \multicolumn{9}{|l|}{ Cephalothorax } \\
\hline \multicolumn{9}{|l|}{ July } \\
\hline Males mature & $\begin{array}{c}0.14 \\
(0.09)\end{array}$ & $\begin{array}{c}5.34 \\
(2.25)\end{array}$ & $\begin{array}{c}0.09 \\
(0.01)\end{array}$ & $\begin{array}{c}2.20 \\
(0.64)\end{array}$ & $\begin{array}{c}0.07 \\
(0.02)\end{array}$ & $\begin{array}{c}0.01 \\
(0.02)\end{array}$ & $\begin{array}{c}0.20 \\
(0.02)\end{array}$ & $\begin{array}{c}0.14 \\
(0.06)\end{array}$ \\
\hline Females vitellogenic & $\begin{array}{c}0.09 \\
(0.16)\end{array}$ & $\begin{array}{c}3.60 \\
(3.27)\end{array}$ & $\begin{array}{c}0.12 \\
(0.12)\end{array}$ & $\begin{array}{c}3.07 \\
(0.84)\end{array}$ & $\begin{array}{c}0.07 \\
(0.02)\end{array}$ & $\begin{array}{c}0.02 \\
(0.02)\end{array}$ & $\begin{array}{c}0.22 \\
(0.06)\end{array}$ & $\begin{array}{c}0.16 \\
(0.05)\end{array}$ \\
\hline spawning & $\begin{array}{c}0.02 \\
(0.03)\end{array}$ & $\begin{array}{c}4.15 \\
(1.79)\end{array}$ & $\begin{array}{c}0.11 \\
(0.08)\end{array}$ & $\begin{array}{c}4.15 \\
(0.85)\end{array}$ & $\begin{array}{c}0.06 \\
(0.03)\end{array}$ & $\begin{array}{c}0.05 \\
(0.01)\end{array}$ & $\begin{array}{c}0.24 \\
(0.04)\end{array}$ & $\begin{array}{c}0.23 \\
(0.13)\end{array}$ \\
\hline postspawn & $\begin{array}{c}0.08 \\
(0.04)\end{array}$ & $\begin{array}{c}2.47 \\
(1.22)\end{array}$ & $\begin{array}{c}0.10 \\
(0.02)\end{array}$ & $\begin{array}{c}2.88 \\
(0.38)\end{array}$ & $\begin{array}{c}0.07 \\
(0.01)\end{array}$ & $\begin{array}{c}0.03 \\
(0.01)\end{array}$ & $\begin{array}{c}0.20 \\
(0.05)\end{array}$ & $\begin{array}{c}0.13 \\
(0.06)\end{array}$ \\
\hline \multicolumn{9}{|l|}{ February } \\
\hline Males sexual rest & $\begin{array}{c}0.34 \\
(0.06)\end{array}$ & $\begin{array}{c}2.78 \\
(0.53)\end{array}$ & $\begin{array}{c}0.22 \\
(0.04)\end{array}$ & $\begin{array}{c}1.43 \\
(0.22)\end{array}$ & $\begin{array}{c}0.07 \\
(0.02)\end{array}$ & $\begin{array}{c}0.08 \\
(0.02)\end{array}$ & $\begin{array}{c}0.35 \\
(0.05)\end{array}$ & $\begin{array}{c}0.20 \\
(0.02)\end{array}$ \\
\hline Females sexual rest & $\begin{array}{c}0.34 \\
(0.18)\end{array}$ & $\begin{array}{c}2.07 \\
(0.64)\end{array}$ & $\begin{array}{c}0.24 \\
(0.13)\end{array}$ & $\begin{array}{c}1.65 \\
(0.84)\end{array}$ & $\begin{array}{c}0.06 \\
(0.04)\end{array}$ & $\begin{array}{c}0.10 \\
(0.05)\end{array}$ & $\begin{array}{c}0.38 \\
(0.19)\end{array}$ & $\begin{array}{c}0.21 \\
(0.12)\end{array}$ \\
\hline \multicolumn{9}{|l|}{ Abdomen } \\
\hline Males mature & $\begin{array}{c}0.01 \\
(0.03)\end{array}$ & $\begin{array}{c}0.34 \\
(0.19)\end{array}$ & $\begin{array}{c}0.05 \\
(0.02)\end{array}$ & $\begin{array}{c}1.40 \\
(0.32)\end{array}$ & $\begin{array}{c}0.02 \\
(0.01)\end{array}$ & $\begin{array}{c}0.00 \\
(0.01)\end{array}$ & $\begin{array}{c}0.17 \\
(0.02)\end{array}$ & $\begin{array}{c}0.09 \\
(0.03)\end{array}$ \\
\hline Females vitellogenic & $\begin{array}{c}0.01 \\
(0.01)\end{array}$ & $\begin{array}{c}0.25 \\
(0.07)\end{array}$ & $\begin{array}{c}0.03 \\
(0.00)\end{array}$ & $\begin{array}{c}1.58 \\
(0.19)\end{array}$ & $\begin{array}{c}0.01 \\
(0.01)\end{array}$ & $\begin{array}{c}0.02 \\
(0.02)\end{array}$ & $\begin{array}{c}0.18 \\
(0.02)\end{array}$ & $\begin{array}{c}0.12 \\
(0.04)\end{array}$ \\
\hline spawning & $\begin{array}{c}0.00 \\
(0.01)\end{array}$ & $\begin{array}{c}0.26 \\
(0.11)\end{array}$ & $\begin{array}{c}0.03 \\
(0.01)\end{array}$ & $\begin{array}{c}1.59 \\
(0.12)\end{array}$ & $\begin{array}{c}0.01 \\
(0.01)\end{array}$ & $\begin{array}{c}0.02 \\
(0.01)\end{array}$ & $\begin{array}{c}0.18 \\
(0.03)\end{array}$ & $\begin{array}{c}0.14 \\
(0.07)\end{array}$ \\
\hline postspawn & $\begin{array}{c}0.01 \\
(0.02)\end{array}$ & $\begin{array}{c}0.35 \\
(0.11)\end{array}$ & $\begin{array}{c}0.05 \\
(0.01)\end{array}$ & $\begin{array}{c}1.37 \\
(0.13)\end{array}$ & $\begin{array}{c}0.02 \\
(0.03)\end{array}$ & $\begin{array}{c}0.01 \\
(0.01)\end{array}$ & $\begin{array}{c}0.17 \\
(0.03)\end{array}$ & $\begin{array}{c}0.12 \\
(0.03)\end{array}$ \\
\hline \multicolumn{9}{|l|}{ February } \\
\hline Males sexual rest & $\begin{array}{c}0.13 \\
(0.06)\end{array}$ & $\begin{array}{c}0.36 \\
(0.16)\end{array}$ & $\begin{array}{c}0.11 \\
(0.03)\end{array}$ & $\begin{array}{c}0.88 \\
(0.18)\end{array}$ & $\begin{array}{c}0.02 \\
(0.01)\end{array}$ & $\begin{array}{c}0.06 \\
(0.01)\end{array}$ & $\begin{array}{c}0.16 \\
(0.01)\end{array}$ & $\begin{array}{c}0.10 \\
(0.01)\end{array}$ \\
\hline Females sexual rest & $\begin{array}{c}0.10 \\
(0.04)\end{array}$ & $\begin{array}{c}0.28 \\
(0.07)\end{array}$ & $\begin{array}{c}0.12 \\
(0.03)\end{array}$ & $\begin{array}{c}0.88 \\
(0.19)\end{array}$ & $\begin{array}{c}0.03 \\
(0.01)\end{array}$ & $\begin{array}{c}0.07 \\
(0.02)\end{array}$ & $\begin{array}{c}0.19 \\
(0.05)\end{array}$ & $\begin{array}{c}0.11 \\
(0.03)\end{array}$ \\
\hline
\end{tabular}

fewer compounds, with higher DAG $(10 \times)$, cholesterol $(2 \times)$ and PG-DPG $(3 \times)$ and lower PC contents for krill at sexual rest in February ( $p<0.05$ in all cases). TAG and $\mathrm{PE}$ contents in the $\mathrm{AB}$ remained at similar levels for the 2 periods. In July, lipid allocation to reproduction for ready-to-spawn females was expressed as an increased proportion of PG-DPG and PC in the CT compared to other females and males ( $p<0.05$ in all cases).

\section{The Kattegat population}

The pattern of lipid distribution of krill from the Kattegat was the reverse of that of krill from the other 2 sites (Table 6). In March, the CT contained significantly higher levels of DAG, TAG, PC, PG-DPG and PE than during the reproductive period in July $(\mathrm{p}<0.05$ in all cases), and similar levels of LPC and PS-PI. In the $\mathrm{AB}$, krill in March contained more PG-DPG $\left(U_{20,50}=\right.$ 11) and PC $\left(U_{20,50}=24\right)$ than summer krill, while other lipids remained at similar levels in both months.

Comparison of the lipid composition in the $\mathrm{CT}$ of reproductive krill in July showed that levels of PC, PG-
DPG and PE were higher for females than for males, while the reverse was observed for the neutral lipids: DAG, TAG and PS-PI ( $p<0.05$ in all cases).

Relative influence of environmental and physiological factors on lipid distribution

A key problem when sampling organisms in their natural environment lies in evaluating the influence of the covariation of both environmental and biological factors on the total variance in the descriptors analysed. We wanted to evaluate separately to what extent the lipid distribution in Meganyctiphanes norvegica is influenced by differences in trophic conditions and stage of the reproductive cycle, and whether or not such lipid structure reflects an adaptation to different physical conditions. Principal components analysis (PCA) is one of the multivariate statistical methods which can achieve such discrimination.

For the cephalothorax, 3 factorial axes were needed to explain $77 \%$ of the total variance. The projection of the data from the different sites on the first factorial 
Table 6. Meganyctiphanes norvegica. Lipid-class distribution in cephalothorax and abdomen of krill from the Kattegat expressed as \% wet weight. Data are means (SD). Abbreviations as in Table 4

\begin{tabular}{|c|c|c|c|c|c|c|c|c|}
\hline & DAG & TAG & Chol. & $\mathrm{PC}$ & LPC & PG-DPG & $\mathrm{PE}$ & PS-PI \\
\hline \multicolumn{9}{|l|}{ Cephalothorax } \\
\hline \multicolumn{9}{|l|}{ July } \\
\hline \multirow[t]{2}{*}{ Males mature } & 0.13 & 1.39 & 0.19 & 0.82 & 0.08 & 0.04 & 0.19 & 0.20 \\
\hline & $(0.03)$ & $(0.58)$ & $(0.03)$ & $(0.21)$ & $(0.02)$ & $(0.02)$ & $(0.04)$ & $(0.05)$ \\
\hline \multirow[t]{2}{*}{ Females vitellogenic } & 0.07 & 0.76 & 0.19 & 1.13 & 0.04 & 0.07 & 0.24 & 0.13 \\
\hline & $(0.02)$ & $(0.28)$ & $(0.03)$ & $(0.19)$ & $(0.03)$ & $(0.03)$ & $(0.03)$ & $(0.01)$ \\
\hline \multirow[t]{2}{*}{ spawning } & 0.08 & 0.91 & 0.17 & 1.44 & 0.05 & 0.06 & 0.23 & 0.10 \\
\hline & $(0.04)$ & $(0.22)$ & $(0.03)$ & $(0.21)$ & $(0.02)$ & $(0.02)$ & $(0.03)$ & $(0.02)$ \\
\hline \multirow[t]{2}{*}{ postspawn } & 0.10 & 0.70 & 0.18 & 1.34 & 0.05 & 0.05 & 0.22 & 0.11 \\
\hline & $(0.05)$ & $(0.20)$ & $(0.04)$ & $(0.19)$ & $(0.02)$ & $(0.02)$ & $(0.03)$ & $(0.02)$ \\
\hline \multicolumn{9}{|l|}{ March } \\
\hline \multirow[t]{2}{*}{ Males sexual rest } & 0.15 & 3.67 & 0.23 & 1.81 & 0.03 & 0.14 & 0.31 & 0.17 \\
\hline & $(0.04)$ & $(1.93)$ & $(0.07)$ & $(0.31)$ & $(0.01)$ & $(0.03)$ & $(0.06)$ & $(0.04)$ \\
\hline \multirow[t]{2}{*}{ Females sexual rest } & 0.12 & 1.56 & 0.22 & 1.57 & 0.04 & 0.08 & 0.28 & 0.13 \\
\hline & $(0.05)$ & $(0.87)$ & $(0.07)$ & $(0.27)$ & $(0.02)$ & $(0.02)$ & $(0.04)$ & $(0.02)$ \\
\hline \multicolumn{9}{|l|}{ Abdomen } \\
\hline \multicolumn{9}{|l|}{ July } \\
\hline \multirow[t]{2}{*}{ Males mature } & 0.09 & 0.18 & 0.14 & 0.58 & 0.03 & 0.03 & 0.16 & 0.12 \\
\hline & $(0.03)$ & $(0.08)$ & $(0.04)$ & $(0.18)$ & $(0.01)$ & $(0.01)$ & $(0.05)$ & $(0.04)$ \\
\hline \multirow[t]{2}{*}{ Females vitellogenic } & 0.05 & 0.33 & 0.15 & 0.65 & 0.01 & 0.03 & 0.19 & 0.10 \\
\hline & $(0.01)$ & $(0.12)$ & $(0.04)$ & $(0.11)$ & $(0.01)$ & $(0.01)$ & $(0.03)$ & $(0.02)$ \\
\hline \multirow[t]{2}{*}{ spawning } & 0.06 & 0.31 & 0.13 & 0.70 & 0.03 & 0.03 & 0.18 & 0.09 \\
\hline & $(0.01)$ & $(0.13)$ & $(0.01)$ & $(0.15)$ & $(0.01)$ & $(0.01)$ & $(0.03)$ & $(0.01)$ \\
\hline \multirow[t]{2}{*}{ postspawn } & 0.08 & 0.33 & 0.14 & 0.73 & 0.04 & 0.04 & 0.19 & 0.09 \\
\hline & $(0.04)$ & $(0.11)$ & $(0.03)$ & $(0.12)$ & $(0.02)$ & $(0.01)$ & $(0.03)$ & $(0.02)$ \\
\hline \multicolumn{9}{|l|}{ March } \\
\hline \multirow[t]{2}{*}{ Males sexual rest } & 0.04 & 0.30 & 0.12 & 1.01 & 0.02 & 0.09 & 0.18 & 0.10 \\
\hline & $(0.01)$ & $(0.20)$ & $(0.02)$ & $(0.12)$ & $(0.01)$ & $(0.02)$ & $(0.03)$ & $(0.02)$ \\
\hline \multirow[t]{2}{*}{ Females sexual rest } & 0.07 & 0.36 & 0.14 & 1.10 & 0.02 & 0.09 & 0.22 & 0.12 \\
\hline & $(0.02)$ & $(0.16)$ & $(0.05)$ & $(0.14)$ & $(0.01)$ & $(0.02)$ & $(0.04)$ & $(0.03)$ \\
\hline
\end{tabular}

plane (Fig. 1B) discriminated the Ligurian Sea reproducing males (LSM) and vitellogenic females (LSV) and the Clyde Sea winter individuals (CW) on the positive side of the first axis (51.1\% of the total variance) from the Clyde sea summer males (CSM), vitellogenic females (CSV) and postspawn females (CSS) on the negative side. The corresponding contributions amount to $45.1 \%$ of the variance explained by Axis 1 on the positive side and $34.9 \%$ on the negative side. Correlation of active variables with Axis 1 (Fig. 1A) indicated changes in the concentration of $\mathrm{PE}$ and the minor lipid classes (DAG, cholesterol, PG-DPG) as major descriptors. The second axis (25.9\% of total variance) separated the Kattegat reproductive females in July from the Clyde Sea ready-to-spawn females (Fig. 1B), with TAG and PC as major descriptors (Fig. 1A). The contribution of the 2 sets of observations accounted for 44.6 and $30 \%$ of the variance explained by Axis 2 respectively. Projection of the illustrative variables revealed that both total lipid content and chl a concentration showed a strong correlation with both TAG and PC. The third axis (not shown) accounted for $7.8 \%$ of the total variance and was related to the opposition of
PG-DPG and PS-PI. Hierarchical clustering (Fig. 2) separated 3 major groups, each differentiated by the combination of their respective levels of minor and major lipid compounds: (1) the Ligurian Sea and Clyde populations in February associated with the dominance of PE and minor compounds (DAG, cholesterol, PG-DPG); (2) the Clyde Sea population in July, with low levels of PE and minor lipids and high levels of TAG and PC; (3) the whole Kattegat population and spent females in the Ligurian Sea, with low levels of TAG and PC and intermediate levels of DAG, cholesterol, PG-DPG and PE.

For the abdomen, 3 axes were also required to explain $86.7 \%$ of the total inertia. The projection of the observations on the first factorial plane (Fig. 3B) revealed a structure along the first axis $(46.9 \%$ of the total variance) similar to that recorded for the cephalothorax, with an additional descriptor on the positive side. The contribution of the different groups confirmed the strong opposition of the Clyde Sea reproductive krill (57.8\% variance of Axis 1) and a group consisting of the Ligurian Sea reproductive males (LSM), and vitellogenic females (LSV), the 
Clyde Sea winter individuals (CW; both sexes) and the postspawn females (KSS) from the Kattegat $(21.8 \%$ variance of Axis 1). The correlation of the lipid classes with the first factorial axis (Fig. 3A) placed DAG, cholesterol and PG-DPG opposite to PC. The second axis ( $26.1 \%$ of the total variance) isolated the Kattegat reproductive males (KSM) and the Ligurian non-repro-

A
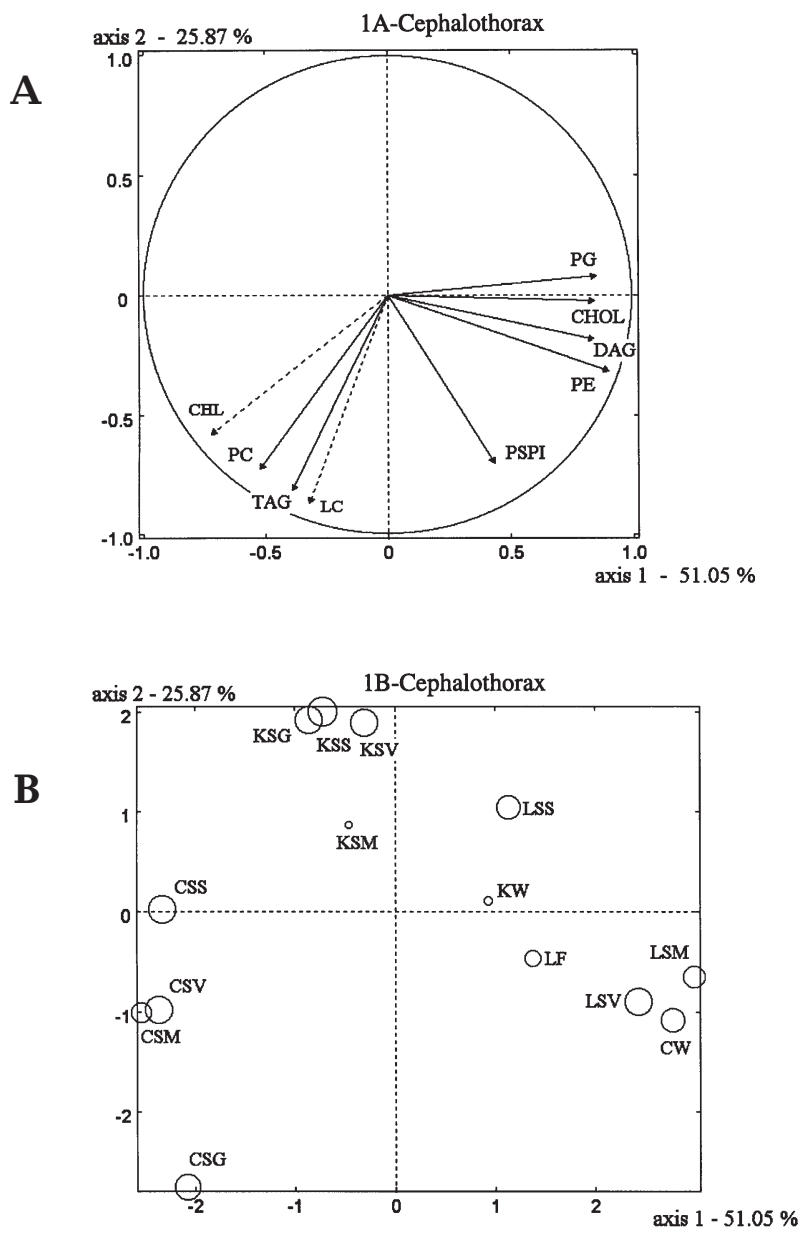

Fig. 1. Meganyctiphanes norvegica. Principal component analysis of lipid-class distribution in cephalothorax for all groups of samples of Ligurian, Clyde and Kattegat populations. (A) Projection of lipid-class descriptors on first factorial plane (Axes 1 and 2) with chl a (CHL) and total lipid content (LC) as illustrative variables (DAG: diacylgycerol; TAG: triacylglycerol; CHOL: chlolesterol; PC: phosphatidylcholine; PG: phosphatidyl-, diphosphatidylglycerol; PE: phosphatidylethanolamine; PS-PI: phosphatidyl-serine, -inositol). (B) Projection of each group of samples at the 3 sites on first factorial plane (LSM: Ligurian spring males; LSV: Ligurian spring vitellogenic females; LSS: Ligurian spring spent females; LF: Ligurian autumn males, females; CSM: Clyde summer males; CSV: Clyde summer vitellogenic females; CSG: Clyde summer gravid females; CSS: Clyde summer spent females; CW: Clyde winter males and females; KSM: Kattegat summer males; KSV: Kattegat summer vitellogenic females; KSG: Kattegat summer gravid females; KSS: Kattegat summer spent females; KW: Kattegat winter males and females

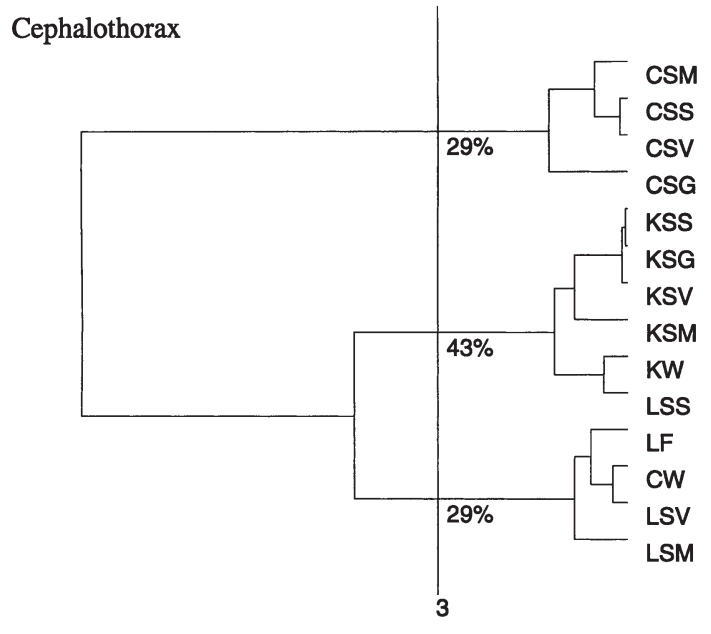

Fig. 2. Meganyctiphanes norvegica. Dendrogram of hierarchical clustering of the different groups of krill cephalothoraxes based on scores of first 5 factorial axes. Abbreviations as in Fig. 1

ductive females (LF) on the positive side from the rest of the data with a contribution of $54 \%$ of the variance explained by the second axis. Interestingly the variables TAG and PE associated with this axis showed negative correlation. Projection of illustrative variables confirmed the close association between PC and chl a but not between PC and total lipids. Hierarchical clustering (Fig. 4) again revealed 3 main groups: (1) the Clyde Sea in July with high levels of PC $(2)$ reproductive females in July and krill in March in the Kattegat, reproductive males and females from the Ligurian Sea, and krill from the Clyde Sea in February with high levels of TAG and $\mathrm{PE}_{i}(3)$ postspawn females and resting krill (autumn) from the Ligurian Sea and reproductive males from the Kattegat with low proportions of TAG and PE.

Fig. 5 shows the relative values of major membrane lipids in the $A B$ as a function of temperature and salinity at the 3 sites in September, February and March (Ligurian Sea: $13^{\circ} \mathrm{C}, 39 \mathrm{psu}$; Clyde Sea: $7^{\circ} \mathrm{C}, 33 \mathrm{psu}$; Kattegat: $\left.3.5^{\circ} \mathrm{C}, 29 \mathrm{psu}\right)$. At $7^{\circ} \mathrm{C}(33 \mathrm{psu})$, levels of cholesterol $\left(U_{20,19}=274\right)$, PG-DPG $\left(U_{20,19}=280\right)$ and PE $\left(U_{20,19}=325\right)$ were significantly higher than at $13^{\circ} \mathrm{C}$ (39 psu), while PC proportions did not vary significantly. At $3.5^{\circ} \mathrm{C}(29 \mathrm{psu})$, PG-DPG $\left(U_{20,20}=79\right)$, PE $\left(U_{20,20}=118\right)$ and PC $\left(U_{20,20}=94\right)$ values were significantly higher than at $7^{\circ} \mathrm{C}$ (33 psu), with no significant changes in cholesterol proportions.

\section{DISCUSSION}

In euphausiids, the distribution and metabolism of triacylglycerol and polar lipids are strongly influenced by trophic environment (Virtue et al. 1993, 
A

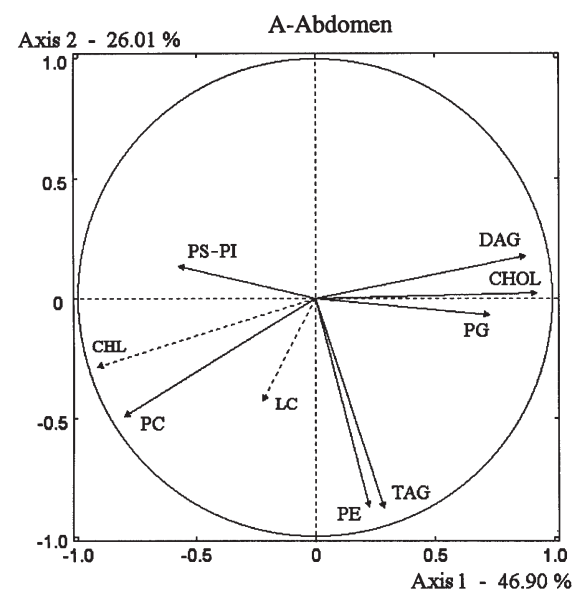

B

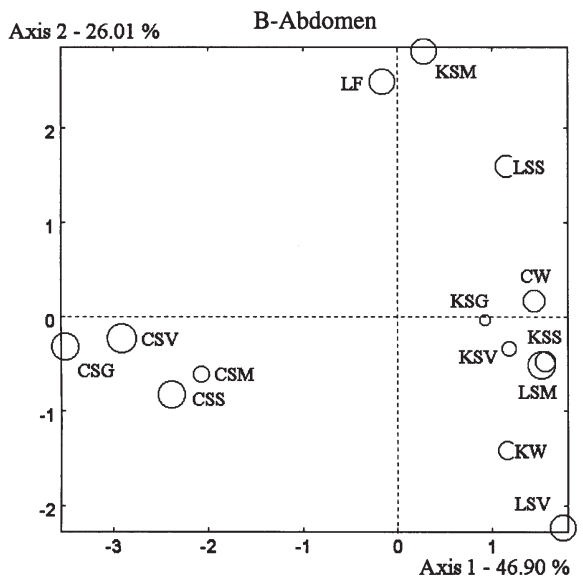

Fig. 3. Meganyctiphanes norvegica. Principal components analysis of lipid-class distribution in abdomen for all groups of samples of Ligurian, Clyde and Kattegat populations. (A) Projection of lipid-class descriptors on first factorial plane (Axes 1 and 2) with chl a (CHL) and total lipid content (LC) as illustrative variables. (B) Projection of each group of samples at the 3 sites on first factorial plane. All abbreviations as in Fig. 1

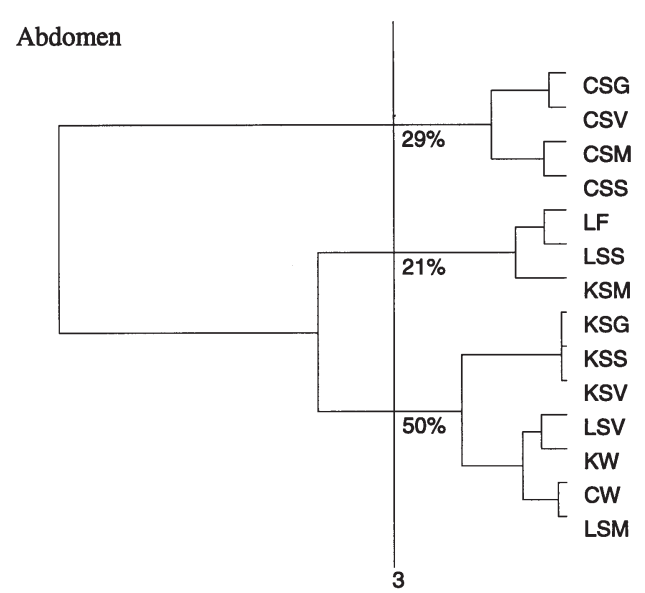

Fig. 4. Meganyctiphanes norvegica. Dendrogram of hierachical clustering of the different groups of krill abdomens based on scores of first 5 factorial axes. Abbreviations as in Fig. 1

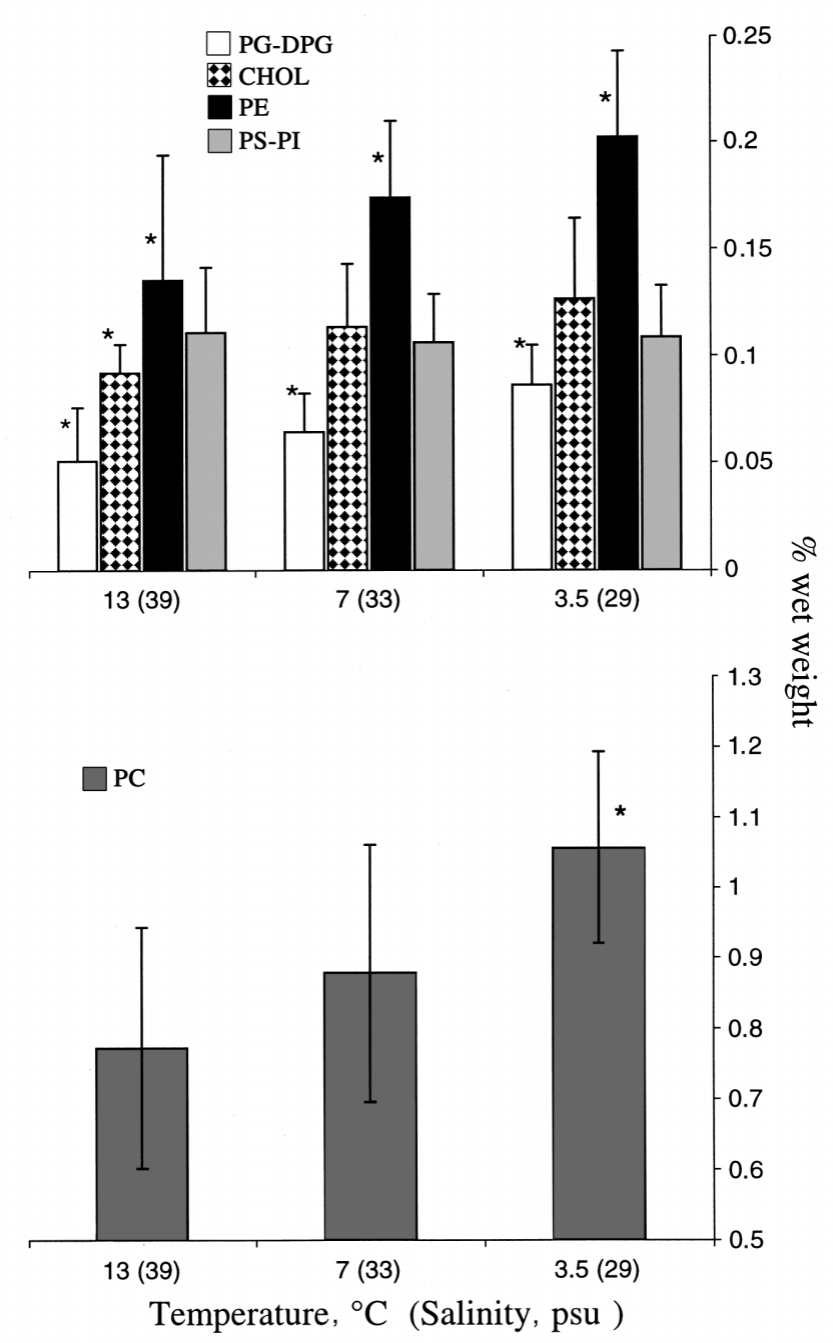

Fig. 5. Meganyctiphanes norvegica. Variation in phospholipid and chlolesterol proportions (\% wet weight) in abdomen as a function of temperature and salinity among the 3 sites. Sites from left to right (abscissa) = Ligurian Sea, Clyde Sea and Kattegat. PG-DPG: phosphatidyl-, diphosphatidylglycerol; other abbreviations as in Fig. 1. ${ }^{*}$ Significant difference at $p<0.05$

Mayzaud 1997) and internal processes such as gonad maturation (Falk-Petersen et al. 1981, Saether et al. 1985, Virtue et al. 1996, Mayzaud et al. 1998, CuzinRoudy et al. 1999). Because krill are pelagic crustaceans, it is difficult to maintain them in in vitro experimental systems, and it is thus difficult to study the ability of euphausiids to acclimate to a variable environment. In the present work, we tried to establish to what extent the lipid composition and metabolism of Meganyctiphanes norvegica are involved in the long-term adaptation of the species to diverse biotic and abiotic parameters of its environment by comparing 3 populations in highly contrasting habitats. 


\section{Size, weight and lipid content}

Among the 3 populations, in April/July the largest individuals were found in the Clyde Sea. During this period, the growth was lower than in the Kattegat and the Ligurian Sea, but their rates of lipid accumulation were higher. Båmstedt (1976) demonstrated that young and thus small krill have the highest growth rates, showing tissue formation with protein as the major constituent. In contrast, large krill (39 mm in the Clyde Sea) have less need of energy reserves for growth. At the time of reproduction they can direct such reserves into this major energy-demanding process and can store lipids when food is in excess. In the Ligurian Sea, the poor correlation between body weight and lipid content resulted from a great variability in total lipid content, which probably reflected local oligotrophic conditions.

\section{Seasonal and geographical variation in total lipid content: influence of trophic conditions}

Seasonal differences in the lipid content of the CT and the $\mathrm{AB}$ of krill were closely related to differences in food supply in both the Ligurian and Clyde Seas (Table 1). Lipid levels of krill in the Ligurian Sea were in agreement with values recorded by Mayzaud et al. (1999), who also recorded an increase in the lipid content from February to April. In contrast to the Ligurian and Clyde Sea populations and in agreement with a previous study of Buchholz \& Prado-Fiedler (1987), krill in the Kattegat had higher lipid levels in March than in July although phyto- and zooplankton concentrations were similar (Table 1, and P. Mayzaud et al. unpubl. data) in both months. Nevertheless, in March, a phytoplankton bloom in surface waters was reported (Matthews et al. 2000) and chl a ingestion rate was 1 order of magnitude higher than in July (0.64 to 0.06 $\mathrm{mg} \mathrm{C} \mathrm{d}^{-1}$ : Table 1). Examination of the lipid content as a function of geographical location for krill at sexual rest (February/March, September) and early in the reproductive period (March) suggested a south-north gradient, with levels increasing in the order Ligurian Sea < Clyde Sea < Kattegat. This was especially true for males $(\mathrm{CT})$; females in the Kattegat tended to be influenced by the previous long breeding season. Higher lipid accumulation at higher latitudes has been observed for many zooplankters (Benson \& Lee 1975), and is directly related to the seasonal pattern of primary and secondary production (Falk-Petersen 1981, Falk-Petersen et al. 1987, Mayzaud et al. 1999) rather than to the direct influence of climate. It is likely that the lipid content of krill in February, March and September was the result of the combined effects of previous lipid storage and expenditure. In the present work, the 'snapshot' method of sampling revealed that food availability and reproduction had a major influence on the lipid content of the krill.

\section{Within-site variation in total lipid content among reproductive stages}

In reproductive krill, large variations in the lipid content occur in females because of development of the ovary (Cuzin-Roudy et al. 1999, Albessard et al. 2001). The determination of reproductive status linked to ovary maturation (Cuzin-Roudy 1993, Cuzin-Roudy \& Buchholz 1999) allowed us to distinguish precisely between vitellogenic, ready-to-spawn and postspawn females. The Ligurian population displayed the clearest pattern of lipid variations among reproductive females. As reported for Euphausia superba (Clarke 1980, Saether et al. 1985, Pond et al. 1995, Mayzaud 1997), gravid female Meganyctiphanes norvegica contained higher amounts of lipids than postspawn females, and in the Ligurian Sea $55 \%$ of the CT lipids were lost through spawning. Indeed, the lipid content increased continuously during a reproductive cycle from postspawn to ready-to-spawn females via vitellogenic stages, matching the model of egg production cycle of Cuzin-Roudy \& Buchholz (1999). In comparison to the Ligurian population, reproductive females in the Clyde Sea displayed higher relative levels of lipids in their $\mathrm{CT}$, but a similar loss in absolute amounts (Clyde Sea $=7 \mathrm{mg}$, Ligurian Sea $=6.2 \mathrm{mg}$ ). Consequently, they lost only $33 \%$ of their CT lipids through spawning, suggesting that their CT lipid content largely covered the needs of egg production. In contrast, female krill in the Kattegat did not seem to lose significant amounts of lipid during egg release. The reproduction period in the Kattegat extended over a longer period (April to October; Boysen \& Buchholz 1984) than in the Ligurian Sea (January to May; Cuzin-Roudy 1993) and the Clyde Sea (April to August; Mauchline \& Fisher 1969), and Kattegat krill potentially underwent more successive spawning cycles coupled with extensive moulting (Cuzin-Roudy \& Buchholz 1999) than in the Clyde and Ligurian Seas. In March 1997, the males were already mature and some of the females were engaged in egg production (Cuzin-Roudy \& Buchholz 1999). Thus, in Kattegatt krill, lipid reserves are likely to be drained continuously over a very long period covering mating activity and egg production resulting in low lipid reserves.

\section{Seasonal variation in lipid class distribution}

The neutral and polar lipid-class distribution of Meganyctiphanes norvegica has recently been well 
documented: TAG is the main lipid reserve (FalkPetersen et al. 1981, Sargent \& Falk-Petersen 1981, Saether et al. 1986, Mayzaud et al. 1999, Albessard et al. 2001) and PC is believed to play an important role in egg production (Cuzin-Roudy et al. 1999, Albessard et al. 2001). In krill, the $C T$, and in particular the digestive gland, is the main site responsible for lipid metabolism (Henderson et al. 1981, 1982) and storage (Mayzaud et al. 1998, Cuzin-Roudy et al. 1999, Albessard et al. 2001). In contrast to the $C T$, the $A B$ is comprised mainly of muscle tissues, and thus reflects the phospholipid composition of the various cell membrane types. For each population generally, most lipid classes in the $\mathrm{AB}$ followed the seasonal variations observed in the CT. Seasonal differences in the TAG and PC levels of the $\mathrm{CT}$ followed a similar pattern in the Ligurian Sea and the Clyde Sea, with higher levels in April and July when food conditions were optimal and when krill were actively reproducing. In the Clyde Sea, the CT levels of TAG and PC in July corresponded to higher phytoplankton ingestion rates (Table 1, P. Mayzaud et al. unpubl. data) than in February. In contrast, reproductive krill in the Kattegat in July had lower levels of most lipids (DAG, TAG, PC, PG-DPG, PE) than in March. In March, the phytol as well as the fatty acid compositions of the stomach contents indicated a more herbivorous diet (Lass et al. 2001). During periods of high primary production, $M$. norvegica appears to adapt to a more herbivorous regime, resulting in the accumulation of TAG and PC for either the supply of essential nutrients (Mayzaud et al. 1998) or for energy production (Hagen et al. 1996).

\section{Variation of lipid class distribution as a function of reproductive state}

The influence of reproduction on lipid-class distribution in the Ligurian and Clyde Seas was expressed by a large decrease in TAG and PC during spawning related to the lipid content loss observed. In a recent paper, we proposed for the Ligurian population of Meganyctiphanes norvegica a lipid metabolism orientated towards phospholipids during reproduction (Albessard et al. 2001). It is likely that this would also apply to the Kattegat population although the reproduction period extends over a longer period than in the Clyde and Ligurian Seas. Although, in contrast to PC, the relative levels of PE were constant, associated with membrane composition (Hagen et al. 1996, Mayzaud 1997), the high levels recorded for reproductive males and females prior to spawning in the Ligurian Sea raises the potential importance of this lipid in gamete production. In a wide variety of marine crustaceans and in Euphausia superba, PE includes high levels of eicosapentaenoic (EPA) and docosahexaenoic (DHA) acids (Clarke 1979, Chapelle 1986, Mayzaud et al. 2000) and could prove a good source of essential polyunsaturated fatty acids (PUFAs) for embryogenesis. Other lipids such DAG, and PG-DPG (krill from the Clyde Sea) or PS-PI (krill from the Ligurian Sea) were present at different levels in gravid and postspawn females, and could be involved to some extent in egg or yolk production.

\section{Relative influence of environmental and physiological factors on lipid distribution}

Our results suggest that in the $\mathrm{CT}$, the distributions of PE and minor lipids (DAG, cholesterol, PG-DPG) are linked with intermediary metabolism, while TAG and PC levels discriminate the 3 krill populations. TAG and PC were both strongly correlated to total lipid content and chl a concentration, indicating a close link between phytoplankton concentration, lipid content and the major lipid classes. Again in the AB, PC was closely associated with chl a concentration. During blooms, as in the Clyde Sea in summer, phytoplankton is particularly rich in essential n-3 PUFAs (Sargent \& Whittle 1981, Fraser \& Sargent 1989) and can be a valuable food source. Moreover, the TAG and PC of Meganyctiphanes norvegica are rich in PUFAs, underlining further the close link between the levels of major lipids and trophic conditions (Virtue et al. 2000).

The distribution of minor membrane lipids (cholesterol, PG-DPG), DAG and PE in the CT could indicate different rates of lipid accumulation among the 3 populations at the time of sampling. Since the reproduction period is chronologically different for each population (Cuzin-Roudy \& Buchholz 1999), the snapshot sampling of the present study has an impact on observed differences in lipid distribution at the 3 sites. A complete comparison of the 3 populations of Meganyctiphanes norvegica requires a continuous annual survey monitoring the intermediary steps in trophic conditions and in the biological cycle of the krill. In the AB, TAG and PE were closely associated and separated those krill experiencing poor food conditions (Kattegat males in July, krill in the Ligurian Sea in September) and warmer temperatures (Ligurian Sea, krill in September) and facing high energy expenditure (Ligurian Sea, postspawn females) from females undergoing in vitellogenesis (Ligurian Sea, Kattegat) or krill from colder environments (Clyde and Kattegat, krill in winter). Although the $\mathrm{AB}$ is not a major site of lipid deposition, here we have a complex combination of 2 factors: (1) the influence of the trophic environment coupled with reproduction associated with TAG, and (2) the underlying impact of different abiotic environments affecting PE. 
By examining the variations in membrane lipids of the abdominal muscular tissue of krill not engaged in reproduction at the different temperatures and salinities of the 3 sites, we tried to evaluate the potential influence of the physical environment on Meganyctiphanes norvegica. We observed outstanding homeostasis of the PS-PI compound. Although the relative abundances of PS and PI could not be evaluated, this suggests that the PS-PI group is not significantly affected by environmental change. In crustacean muscles, PS and PI are relatively rich in arachidonic acid (AA), a precursor of prostaglandins (Chapelle 1986) which are involved in the regulation of cellular metabolism in vertebrates (Alberts et al. 1986, Voet \& Voet 1990). Although we lack details of the composition of PS and PI in krill, these lipids could play a similar role in $M$. norvegica as that proposed for other crustaceans (Chapelle 1986). The PG-DPG contents clearly separated krill in the Kattegat in March from those of the warmer and saltier Ligurian Sea in September. DPG (cardiolipin) plays an important role in ATP production (Ohtsuka et al. 1993, Jiang et al. 2000), and in the function of various membrane proteins (Daum 1985) in the internal membrane of the mitochondria. In crab gills and fish muscles, DPG content and metabolism have also been found to increase with decreasing salinity (Chapelle \& Zwingelstein 1984, Glémet et al. 1997), but not with temperature (Wodtke 1981, Pruitt 1988). It is therefore probable that, in order to maintain a proper functioning of muscle mitochondria, changes in PG-DPG content of $M$. norvegica are more related to changes in salinity than to changes in temperature. In addition to increases in PC and PE unsaturation (Chapelle 1978) as well as hydrophilic head substitution from PC to PE (Chapelle 1986) with decreasing temperature, quantitative modifications in the $\mathrm{PE}$ and $\mathrm{PC}$ of muscles and hemolymph in crustaceans have been observed (Chapelle et al. 1977, Brichon et al. 1980). In the present study, the PE proportions differed among the 3 sites. In contrast, the PC proportions were only significantly higher at $3.5^{\circ} \mathrm{C}$, and the cholesterol proportions only between 13 and $7^{\circ} \mathrm{C}$. Although these differences are small, they indicate that $M$. norvegica can adapt to different environmental temperatures by specifically modulating its membrane phospholipids. As the membrane composition has to be maintained within genetically predetermined limits, variations in the physiological range of temperature are necessarily subtle.

In conclusion, the adaptation of Meganyctiphanes norvegica to very different habitats involves lipid storage, distribution and metabolism. Lipids are modulated not only to provide energy but also to achieve an efficient functioning of the whole organism, in part by adapting their membrane composition. Trophic conditions are the main factors differentiating lipid storage within and between populations of krill. In this connection, the lipid-class distribution is regulated by the physiology of the krill during reproduction. Environmental abiotic parameters such as temperature and salinity are likely to induce regulation of membrane phospholipids to ensure homeostasis in this organism. These mechanisms are the keys to the evolutionary success of this species.

Acknowledgements. E.A. was supported by a grant from the government of Luxemburg provided by the 'Ministère de l'Education Nationale et de la Formation Professionnelle'. This study forms part of the project 'Impact of a climate gradient on the physiological ecology of a pelagic crustacean' (PEP) of EU MAST III program, contract \#MAS3 CT-95-0013. We would like to thank the captain and crew of the FS 'Heincke' and all PEP members for their support and their team spirit. We are particularly grateful to Dr. J. Cuzin-Roudy for her valuable comments on krill reproduction and the statistics, and to Dr. E. Rochelle Newall for correcting the English grammar.

\section{LITERATURE CITED}

Ackman RG (1981) Application of flame ionization detector to thin layer chromatography on coated quartz rods. Methods Enzymol 72:205-252

Alberts B, Bray D, Lewis J, Raff M, Roberts K, Watson JD (1986) Molecular biology of the cell. Garland Publishing, New York

Albessard E, Mayzaud P, Cuzin-Roudy J (2001) Variation of lipid classes among organs of the northern krill Meganyctiphanes norvegica, with respect to reproduction. Comp Biochem Physiol A 129:373-390

Angelo AJ St, James C Jr (1993) Analysis of lipids from cooked beef by thin layer chromatography with flame ionization detection. J Am Oil Chem Soc 70:1245-1250

Astthorsson OS, Gislason A (1997) Biology of euphausiids in the subarctic waters north of Iceland. Mar Biol 129: 319-330

Båmstedt U (1976) Studies on the deep-water pelagic community of Korsfjorden, western Norway: changes in the size and biochemical composition of Meganyctiphanes norvegica (Euphausiacea) in relation to its life cycle. Sarsia 61:15-30

Båmstedt U, Karlson K (1998) Euphausiid predation on copepods in coastal waters of the Northeast Atlantic. Mar Ecol Prog Ser 172:149-168

Benson AA, Lee RF (1975) The role of wax in oceanic food chains. Sci Am 232:77-86

Bligh ED, Dyer W (1959) A rapid method of total lipid extraction and purification. Can J Biochem Physiol 37:911-917

Boysen E, Buchholz F (1984) Meganyctiphanes norvegica in the Kattegat: studies on the annual development of a pelagic population. Mar Biol 79:195-207

Brichon G, Chapelle S, Zwingelstein G (1980) Phospholipid composition and metabolism in the hemolymph of Carcinus maenas (Crustacea, Decapoda): effect of temperature. Comp Biochem Physiol B 67:647-652

Buchholz F, Prado-Fiedler R (1987) Studies on the seasonal biochemistry of the northern krill Meganyctiphanes norvegica in the Kattegat. Helgol Meeresunters 41:443-452

Chapelle S (1978) The influence of acclimation temperature 
on the fatty acid composition of an aquatic crustacean (Carcinus maenas). J Exp Zool 204:337-346

Chapelle S (1986) Aspects of phospholipid metabolism in crustaceans as related to changes in environmental temperatures and salinities. Comp Biochem Physiol B 84: 423-439

Chapelle S, Zwingelstein G (1984) Phospholipid composition and metabolism of crustacean gills as related to changes in environmental salinities. Relationship between $\mathrm{Na}^{+}$, $\mathrm{K}^{+}$-ATPase activity and phospholipids. Comp Biochem Physiol B 78:363-372

Chapelle S, Meister R, Brichon G, Zwingelstein G (1977) Influence of temperature on the phospholipid metabolism of various tissues from the crab Carcinus maenas. Comp Biochem Physiol B 58:413-417

Clarke A (1979) Lipid content and composition of the pink shrimp, Pandalus montagui (Leach) (Crustacea: Decapoda). J Exp Mar Biol Ecol 38:1-17

Clarke A (1980) The biochemical composition of krill Euphausia superba Dana, from South Georgia. J Exp Mar Biol Ecol 43:221-236

Cuzin-Roudy J (1993) Reproductive strategies of the Mediterranean krill Meganyctiphanes norvegica and the Antarctic krill Euphausia superba (Crustacea: Euphausiacea) Invertebr Reprod Dev 23:105-114

Cuzin-Roudy J (2000) Seasonal reproduction, multiple spawning, and fecundity in northern krill, Meganyctiphanes norvegica, and Antarctic krill, Euphausia superba. Can J Fish Aquat Sci 57 (Suppl 3):1-10

Cuzin-Roudy J, Buchholz F (1999) Ovarian development and spawning in relation to the moult cycle in northern krill Meganyctiphanes norvegica (Crustacea: Euphausiacea) along a climatic gradient. Mar Biol 133:267-281

Cuzin-Roudy J, Albessard E, Virtue P, Mayzaud P (1999) The scheduling of spawning with the moult cycle in northern krill (Crustacea: Euphausiacea): a strategy for allocating lipids to reproduction. Invertebr Reprod Dev 36:163-170

Dagg MJ, Walser WE (1987) Ingestion, gut passage time and egestion by the copepod Neoclanus plumchrus in the laboratory and in the subarctic Pacific Ocean. Limnol Oceanogr 32:178-188

Daum G (1985) Lipids of mitochondria. Biochim Biophys Acta 822:1-42

De la Bigne C (1985) Etude du métabolisme nutritionnel et des variations spatio-temporelles de l'environnement trophique potentiel de Meganyctiphanes norvegica. PhD thesis, l'Université Pierre et Marie Curie, Paris

Einarsson H (1945) Euphausiacea. I. Northern Atlantic species. Dana Rep 27:1-175

Falk-Petersen S (1981) Ecological investigations on the zooplankton community of Balsfjorden, northern Norway: seasonal changes in body weight and the main biochemical composition of Thysanoessa inermis (Krøyer), Thysanoessa raschii (M. Sars) and Meganyctiphanes norvegica (M. Sars) in relation to environmental factors. J Exp Mar Biol Ecol 49:103-120

Falk-Petersen S, Gatten RR, Sargent JR, Hopkins CCE (1981) Ecological investigations on the zooplankton community in Balsfjorden, northern Norway: seasonal changes in the lipid class composition of Meganyctiphanes norvegica (M. Sars), Thysanoessa raschii (M. Sars), and T. inermis (Krøyer). J Exp Mar Biol Ecol 54:209-224

Falk-Petersen S, Sargent JR, Tande KS (1987) Lipid composition of zooplankton in relation to the sub-arctic food web. Polar Biol 8:115-120

Fraser AJ, Sargent JR (1989) Formation and transfer of fatty acids in an enclosed marine food chain comprising phyto- plankton, zooplankton and herring (Clupea harengus L.) larvae. Mar Chem 27:1-18

Glémet HC, Gerrits MF, Ballantyne JS (1997) Membrane lipids of red muscle mitochondria from land-locked and sea-run Arctic char, Salvenius alpinus. Mar Biol 129:673-679

Hagen W, van Vleet ES, Kattner G (1996) Seasonal lipid storage as overwintering strategy of Antarctic krill. Mar Ecol Prog Ser 134:85-89

Henderson RJ, Sargent JR, Falk-Petersen S (1981) Lipogenesis in the Arctic euphausiid Thysanoessa inermis. Mar Biol 63:235-240

Henderson RJ, Falk-Petersen S, Sargent JR (1982) The composition and biosynthesis of lipids in Thysanoessa raschi from the Clyde estuary, Scotland. Mar Biol 70:7-12

Holm-Hansen O, Lorenzen CJ, Holmes RW, Strickland JDH (1965) Fluorometric determination of chlorophyll. J Cons Perm Int Explor Mer 30:3-15

Isaacs JD, Kidd LW (1953) Isaacs-Kidd mid-water trawl. Scripps Institute of Oceanography, La Jolla Ref 53:18

Jiang F, Ryan MT, Sclame M, Zhao M, Gu Z, Klingenberg M, Pfanner N, Greenberg ML (2000) Absence of cardiolipin in the crd1 null mutant results in decreased mitochondrial membrane potential and reduced mitochondrial function. J Biol Chem 275:22387-22394

Lass S, Tarling GA, Virtue P, Matthews JBL, Mayzaud P, Buchholz F (2001) On the food of northern krill (Meganyctiphanes norvegica) in relation to its vertical distribution. Mar Ecol Prog Ser 214:177-200

Lebart L, Morineau A, Piron M (1995) Statistique exploratoire multidimensionelle. Dunod, Paris

Legendre L, Legendre P (1984) Ecologie numérique, 2ième édn. Tome 2: La structure des données écologiques. Masson eds, Paris, et les Presses del l'Université de Québec

Lindley JA (1982) Population dynamics and production of euphausiids. III. Meganyctiphanes norvegica and Nyctiphanes couchi in the North Atlantic Ocean and the North Sea. Mar Biol 66:37-46

Matthews JBL, Buchholz F, Saborowski R, Tarling GA, Dallot S, Labat JPL (1999) On the physical oceanography of the Kattegat and Clyde Sea area, 1996-98, as background to ecophysiological studies on the planktonic crustacean, Meganyctiphanes norvegica (Euphausiacea). Helgol Meeresunters 53:70-84

Matthews JBL, Tarling GA, Dallot S, Lass S, Bedo A, Buchholz F, Mayzaud P, Saborowski R (2000) The trophic environment of the euphausiid, Meganyctiphanes norvegica in the Kattegat, the Clyde Sea Area and the Ligurian Sea: chlorophyll concentrations and zooplankton biomass and species composition. Internal Report No. 227. Scottish Association for Marine Science, Oban, Argyll

Mauchline J, Fisher LR (1969) The biology of euphausiids. Adv Mar Biol 7:1-454

Mayzaud P (1997) Spatial and life cycle changes in lipid and fatty acid structure of the Antarctic euphausiid Euphausia superba. In: Battaglia B, Valencia J, Walton DWH (eds) Antarctic communities. Cambridge University Press, Cambridge, p 284-294

Mayzaud P, Albessard E, Cuzin-Roudy J (1998) Changes in lipid composition of the Antarctic krill Euphausia superba in the Indian sector of the Antarctic Ocean: influence of geographical location, sexual maturity stage and distribution among organs. Mar Ecol Prog Ser 173: 149-162

Mayzaud P, Virtue P, Albessard, E (1999) Seasonal variations in the lipid and fatty acid composition of the euphausiid Meganyctiphanes norvegica from the Ligurian Sea. Mar Ecol Prog Ser 186:199-210 
Mayzaud P, Albessard E, Virtue P, Boutoute M (2000) Environmental constraints on the lipid structure and metabolism of euphausiids: case of Euphausia superba and Meganyctiphanes norvegica. Can J Fish Aquat Sci 57:1-13

Ohtsuka T, Nishijima M, Suzuki K, Akamatsu Y (1993) Mitochondrial dysfunction of a cultured Chinese hamster ovary cell mutant deficient in cardiolipin. J Biol Chem 268: 22914-22919

Onsrud MSR, Kaartvedt S (1998) Diel vertical migration of the krill Meganyctiphanes norvegica in relation to physical environment, food and predators. Mar Ecol Prog Ser 171: 209-219

Pearcy WG, Hopkins CCE, Gronvik S, Evans RA (1979) Feeding habits of cod, capelin and herring in Balsfjord, northern Norway, July-August 1978: the importance of euphausiids. Sarsia 67:269-277

Pond D, Watkins J, Priddle J, Sargent J (1995) Variation in the lipid content and composition of Antarctic krill Euphausia superba at South Georgia. Mar Ecol Prog Ser 117:49-57

Pruitt NL (1988) Membrane lipid composition and overwintering strategy in thermally acclimated crayfish. Am J Physiol 254: R870-R876

Saether O, Ellingsen TE, Mohr V (1985) The distribution of lipid in the tissues of Antarctic krill, Euphausia superba. Comp Biochem Physiol 81B:609-614

Saether O, Ellingsen TE, Mohr V (1986) Lipids of North Atlantic krill. J Lipid Res 27:274-285

Sargent JR, Falk-Petersen S (1981) Ecological investigations on the zooplankton community in Balsfjorden, northern Norway: lipids and fatty acids in Meganyctiphanes norvegica, Thysanoessa raschi and $T$. inermis during mid-winter. Mar Biol 62:131-137

Sargent JR, Whittle KJ (1981) Lipids and hydrocarbons in the marine food web. In: Longhurst AR (ed) Analysis of marine

Editorial responsibility: Otto Kinne (Editor), Oldendorf/Luhe, Germany ecosystems. Academic Press, London, p 491-533

Sokal RR, Rohlf FJ (1981) Biometry: the principles and practice of statistics in biological research, 2nd edn. WH Freeman, New York

Virtue P, Nicol S, Nichols PD (1993) Changes in the digestive gland of Euphausia superba during short-term starvation: lipid class, fatty acid and sterol content and composition. Mar Biol 117:441-448

Virtue P, Nichols PD, Nicol S, Hosie, G (1996) Reproductive trade-off in male Antarctic krill, Euphausia superba. Mar Biol 126:521-527

Virtue P, Mayzaud P, Nichols P, Albessard E (2000) The use of fatty acids as dietary indicators in krill, Meganyctiphanes norvegica, from north-eastern Atlantic, Kattegat and Mediterranean during summer and winter. Can J Fish Aquat Sci 57(Suppl 3):10-20

Voet D, Voet JG (1990) Lipids and membranes, lipid metabolism in biochemistry. John Wiley \& Sons, New York

Ward JH (1963) Hierarchical grouping to optimize an objective function. J Am Stat Assoc 58:236-244

Wiebe PH, Burt KH, Boyd SH, Morton AW (1976) A multiple opening closing net and environmental sensing system for sampling zooplankton. J Mar Res 34:313-326

Wilkinson L (1996) Systat 7.0: new statistics. SPSS, Chicago

Wodtke E (1981) Temperature adaptation of biological membranes: the effects of acclimation temperature on the unsaturation of the main neutral and charged phospholipids in mitochondrial membranes of the carp (Cyprinus carpio L.). Biochim Biophys Acta 640:698-709

Zane L, Ostellari L, Maccatrozzo L, Bargelloni L, CuzinRoudy J, Buchholz F, Paternello T (2000) Genetic differentiation in a pelagic crustacean (Meganyctiphanes norvegica: Euphausiacea) from the North East Atlantic and the Mediterranean Sea. Mar Biol 136:191-199

Submitted: February 16, 2001; Accepted: December 5, 2002 Proofs received from author(s): April 24, 2003 